\title{
NOTE
}

\section{ZONING VARIANCES AND EXCEPTIONS: THE PHILADELPHIA EXPERIENCE*}

With the comparatively recent advent of the concept of zoning, ${ }^{1}$ numerous legal problems relating to the application, enforcement and constitutionality ${ }^{2}$ of ordinance provisions have arisen in courts throughout the country. Since most ordinances contain some provision for lessening the rigidity of the ordinance as applied in individual instances, ${ }^{3}$ a number of these cases ${ }^{4}$ concern the problem of attempting to determine when, and under what circumstances, these deviations, termed variances and exceptions, should be granted. This Note, after a brief review of statutory authorization, will compare the Pennsylvania courts' relatively few pronouncements on the subject with the practical operations of the administrative agency, known as the Zoning Board of Adjustment, created under the Philadelphia Zoning Ordinance primarily for the purpose of granting variances and exceptions.

\section{Statutory Authorization}

Since the zoning power is an exercise of the state's police power in protecting the health, welfare and safety of its citizens, the municipality depends upon delegation of authority from the state. ${ }^{5}$ Many states have adopted the so-called standard enabling act; ${ }^{\mathbb{B}}$ Pennsylvania enacted it for

* This study was financed by a grant from the Thomas Skelton Harrison Foundation, an agency created by the will of Thomas Skelton Harrison to promote good government in Philadelphia.

The Law Review wishes to express its appreciation for the cooperation and assistance of the members of the Philadelphia Zoning Division and Zoning Board of Adjustment.

1. The first comprehensive zoning statute was enacted in New York City in 1916, but the real zoning impetus did not begin until the early 1920's. 1 YokLEY, Zoning Law and Practice 7 (2d ed. 1953).

2. The most recent constitutional controversy in Pennsylvania, and other states, involves ordinances requiring a certain minimum inhabitable floor area. In at least one instance, Pennsylvania has held such an ordinance unconstitutional. Medinger Appeal, $377 \mathrm{~Pa} .217,104$ A.2d 118 (1954). For a discussion of the merits of this type of ordinance see Nolan and Horack, How Small a House?, 67 HARv. L. Rev. 967 (1954) ; Haar, In Brief Reply, 67 HARv. L. Rev. 986 (1954); Haar, Zoning for Minimum Standards, 66 HARV. L. Rev. 1051 (1953).

3. Green, The Power of the Zoning Board of Adjustment to Grant Variances from the Zoning Ordinance, 29 N.C.L. Rev. 245 (1951).

4. See cases collected in 1 YoKLEY, op. cit. supra note 1 , at 312 and Note, 168 A.L.R. 13 (1947).

5. Kline v. Harrisburg, 362 Pa. 438, 68 A.2d 182 (1949).

6. In 1923 the Department of Commerce of the United States promulgated a model enabling act, which Pennsylvania followed rather closely. Crarg, PENnsyL- 
cities of the first class in 1929. The Act, in addition to establishing the procedure for enacting and amending a zoning ordinance, ${ }^{8}$ authorizes the municipality to designate for districts specified by its local legislative body the uses which may be made of land and structures, the density of population, and the height and locational ${ }^{9}$ requirements of buildings or structures on the land. ${ }^{10}$ A Bureau of Zoning, to be attached to the Department of Public Works, ${ }^{11}$ is required for the enforcement of the ordinance. In addition, the mayor, with council approval, is directed to appoint a five$\operatorname{man}^{12}$ Zoning Board of Adjustment which is empowered to hear and decide appeals challenging any decision made by an administrative official in the interpretation of the provisions of the Act or of an ordinance adopted pursuant to the Act; to hear and decide special exceptions to the terms of the ordinance; and "to authorize, upon appeal, in specific cases, such variance from the terms of the ordinance as will not be contrary to the public interest, where, owing to special conditions, a literal enforcement of the provisions of the ordinance will result in unnecessary hardship, and so that the spirit of the ordinance shall be observed and substantial justice done." 13

vania Building and Zoning Laws 149 (1951). In Pennsylvania each type of municipality has its individual enabling act, but they differ in only minor respects. Ibid; Faught, Zoning Under Changing Conditions in Pemsylvania, 10 U. of PITT. L. REv. 311,317 (1949).

7. PA. Stat. ANN. tit. 53, §3822 et seq. (1953).

8. Id. at $\$ \S 3825-28$.

9. Most ordinances provide for setback, court, side and rear yard requirements, and also establish a minimum open area for the property. When used in this Note, unless otherwise specified, "location" or "locational" will refer to these dimensional requirements.

10. PA. Stat. ANN. tit. 53, §§3822-23 (1953).

11. Id. at $\$ 3830$. The Philadelphia City Charter, having revamped the entire city administrative system, places the Bureau of Zoning, re-named the Zoning Division, in the Department of Licenses and Inspections. Phila. Home Rule Ceartera \$ 5-1002 (a), 1951 Ordinances of The City of Philadelphia 1201. The argument has been made that, since the Philadelphia Ordinance does not meet the requirement that an ordinance be in strict conformity, with the enabling act (see Kline v. Harrisburg, 362 Pa. 438, 68 A.2d 182 (1949)), Philadelphia will not have a legal zoning ordinance until a new one is enacted under the City Charter. Freeman, Has Zoning in Philadelphia Been Anaesthetized?, 26 TEMP. L.Q. 22 (1952). For a reply to this contention see R. Cohen and Stander, The New Charter Has Not Repealed Zoning Authority in Philadelphia, Legal Intelligencer (Philadelphia), Sept. 16, 1952, p. 1, col. 1.

The general powers granted by the Home Rule Enabling Act to cities of the first class for local self-government would seem broad enough to include the power to zone. PA. Stat. ANN. tit. 53, $\$ 3421.17$ (1953). Nor would the Zoning Enabling Act for cities of the first class seem to preclude the exercise of this power through the enactment of a new zoning ordinance under the Home Rule Enabling Act, since the power to zone does not seem to fall within any of the specific limitations on the broad grant of local governmental power. Id. \$3421.18.

12. The Charter has also increased the membership of the Board from five to six members. Phila. Home Rule Charter § 3-911, 1951 Ordinances of the City of PeILA. 1172. The new member is the Commissioner of the Department of Licenses and Inspections who is appointed by the Managing Director with the approval of the Mayor. Phila. Home Rule Charter \$3-206(a), id, at 1161. The other five members are appointed by the Mayor without any requirement of City Council approval. Phila. Home Rule Charter \$3-207, id. at 1162. For other minor changes made by the Charter see Freeman, supra note 11 .

13. Pa. Star. AnN tit. 53, \$3829 (1953). 
Although the Board is authorized to act in these three enumerated instances, the majority of the cases involve only variances. The verbose standard in the ordinance ordinarily is reduced to requiring the applicant to prove that strict enforcement of the ordinance would impose some type of an unnecessary hardship on his use of the particular property, since the public interest, or the interest of surrounding property owners, is sufficiently protected by the inclusion of the term "unnecessary." 14 In Pennsylvania and most other states which have enacted similar provisions, this standard has been held sufficient for a valid delegation of administrative power which does not give the Board a legislative function. ${ }^{15}$

Because of the confusion that has been engendered by interchanging the terms variance and exception, they should be clarified at this point An exception relates to a use which is specified in the ordinance, and may be granted by the Board in conformity with a stated general standard; a variance is appropriate where a use is not permitted in the particular district, or where the property does not conform to the height or locational requirements for a particular use in the district. ${ }^{18} \mathrm{~A}$ variance generally is considered in relation to the land, and not as personal to the applicant seeking the variance, since the condition of the property in comparison with the surrounding uses is the purported justification for the deviation from the ordinance; consequently, even though the applicant may lease or sell the property, the particular use remains on the land.17 An authorization either to erect a building, or to extend an existing building, which would not meet the height or locational requirements is termed a zoning variance. The other kind of variance, a use variance, may be divided into two types. In the first, the applicant is permitted to commence a use or to continue a use, although the ordinance does not provide for this type of use in the district in which the applicant's property is located; in the second, the Board authorizes the applicant to change an existing use to another type of use which, although permitted in the district, would not meet the locational requirements. ${ }^{18}$

One of the classic theories for providing a Board of Adjustment is that it is a means to avoid the constitutional question of deprivation of property which might otherwise arise. However, the more plausible and widely-supported theory is that, since a zoning ordinance cannot be framed

14. See Green, supra note 3 , at 249 .

15. Huebner v. Philadelphia Sav. Fund Soc'y, $127 \mathrm{~Pa}$. Super. 28, 192 Atl. 139 (1937) ; BASSETT, ZoNING 142 (1st ed. 1936). For an explanation and a discussion of the procedure used where the standard was held not to be sufficient see Comment, Zoning Amendments and Variations, and Neighborhood Decline in Illinois, 48 N.W.U.L. REv. 470 (1953) (Zoning Board holds hearings and presents findings to the City Council, which either grants or denies the variance by legislative amendment to the ordinance).

16. See Devereux Foundation, Inc., Zoning Case, $351 \mathrm{~Pa} .478,483,41$ A.2d 744, 746 (1945); Craig, Pennsylvania Butlding and Zoning Laws 243 (1951).

17. See Green supra note 3 , at 265-68.

18. The most common example of this type of variance is found in requests for multiple dwellings. See note 83 infra. 
to treat everyone with justice and encompass every situation, some agency is needed to alleviate the situations where the harm to a particular individual outweighs the value that would be derived by the community if strict adherence to the ordinance were maintained. ${ }^{9}$ Any person aggrieved by a decision of the administrative officer may appeal to the Board. ${ }^{20}$ In most cases the appellant is the property owner who has been denied a permit. The Board is required to hold a public hearing and to keep minutes of its proceedings showing the vote of each member, four being required for a finding in the appellant's favor. ${ }^{21}$ Appeal of the Board's action may be made to a court of record, ${ }^{22}$ and in most cases the appeal is taken either by the applicant or by the neighboring property owners. The Board is required to set forth the reasons for its decision, and the court is authorized to take additional evidence if necessary for a proper disposition of the case. ${ }^{23}$

\section{Present Status of the Court Decisions}

In spite of the fact that the power to grant variances enables the Board of Adjustment to defeat, as well as to effectuate, the goals of a zoning ordinance, the Pennsylvania courts have not defined with any degree of certainty the meaning of "unnecessary hardship." However, certain principles have emerged from the cases, which to an extent limit the Board's extensive discretion. From the procedural viewpoint, the Board generally is required to support its conclusions with findings of fact and reasons for its action, ${ }^{24}$ and, if a variance is refused, the applicant at least must have had the opportunity of securing the number of votes which the statute requires. ${ }^{25}$ When the courts of common pleas have taken additional testimony, the extent to which they have relied on the Board's findings as compared with the additional evidence taken in court, has varied widely. ${ }^{26}$ The courts also give emphatic admonitions to the Board to refrain from granting a variance for a large area, ${ }^{27}$ thus giving

19. Note, Discretionary Powers of Zoning Boards of Adjustment in Pennsylvania, 97 U. of PA. L. Rev. 68, 69 (1948) ; BASSETT, Zoning 165 (1st ed. 1936).

20. PA. Stat. ANN. tit. 53, $\$ 3829$ (1953). In Philadelphia, the administrative officer is a member of the Zoning Division where the application for the use or zoning permit is first made. See text following note 65 infra.

21. Ibid.

22. Ibid.

23. Ibid.

24. Imperial Asphalt Corp. Zoning Case, $359 \mathrm{~Pa}$. 402, 59 A.2d 121 (1948).

25. Hinton v. Zoning Bd. of Adjustment, $86 \mathrm{~Pa}$. D. \& C. 192 (Philadelphia C.P. 1953).

26. The courts may use the testimony to supplement or clear up ambiguities in the Board's findings, make an independent decision of their own, ignoring the Board's findings, or refuse to take any testimony and send the case back to the Board for additional evidence.

27. Dunlap Appeal, $370 \mathrm{~Pa}$ 31, 35, 87 A.2d 299, 301 (1952) ; Lukens v. Ridley Township Zoning Bd. of Adjustment, $367 \mathrm{~Pa} .608,613,80 \mathrm{~A} .2 \mathrm{~d}$ 765, 767 (1951); Sunnybrook, Inc. v. Upper Dublin Township, 75 Pa. D. \& C. 385, 390 (Montgomery C.P. 1950); Sloan's Appeal, 30 Del. Co. (Pa.) 555, 558 (1941). 
rise to the practical problem of determining when an area becomes too large for the utilization of the variance procedure. On the other hand, although some ordinances permit the resumption of a discontinued nonconforming use, at least within a stated time limit, or a change in the type of non-conforming use, ${ }^{28}$, it has been held in one instance that a variance must be obtained if the new use is of a different class from that for which the district is zoned. ${ }^{29}$ Moreover, an attack on the constitutionality of the ordinance as applied to a particular property must be accomplished through the variance procedure before the Board, and not in an independent action..$^{30}$ The Board may attach to a variance any condition that it considers necessary, if the condition is reasonably . related to the health, safety and welfare of surrounding property owners. ${ }^{31}$

Aside from the general platitudes that variances may be granted only for "substantial and compelling reasons," the most firmly entrenched and reiterated declaration is that mere financial hardship or an increased return from the property is not a sufficient reason for granting a variance. ${ }^{32}$ This principle was probably given its extreme application in a case which refused a variance for a fraternity house in a residential single-family neighborhood. ${ }^{33}$ Because of its size the property was particularly adapted for multi-family use and, since the applicant was unable either to sell or to rent it for any of the uses permitted in the district, the property had been vacant for approximately thirteen years. Nevertheless, the court affirmed the Board's refusal, mainly because of the adverse effects which the variance would have had on surrounding property owners. However, in one of the two cases in which the Pennsylvania Supreme Court has reversed a use refusal by the Board, the court recognized the fact that financial advantage is not entirely irrelevant and listed it as one of the reasons for its reversal. ${ }^{34}$ Another factor which appears to have a strong

28. E.g., Phila. Zoning Ordinance $\$ 4(1)$, (2), as amended, 1950 Ordinances of the City of Philadelphia 27. See Craig, Pennsylvania Building and ZoNING LAws 226, 233, 234 (1951). For a recent discussion of non-conforming uses see Note, Non-conforming Uses: $A$ Rationale and an Approach, $102 \mathrm{U}$. of PA. L. REV. 91 (1953).

29. Thus if a commercial use was situated in a residential district, the only change or resumption of a discontinued use that would be permitted would be for a use permitted in a residential district. Darling v. Zoning Bd. of Adjustment, 357 Pa. 428, 54 A.2d 829 (1947).

30. Taylor v. Moore, 303 Pa. 469, 154 Atl. 799 (1931).

31. Gish v. Exley, 153 Pa. Super. 653, 34 A.2d 925 (1943); Appeal of Consolidated Cleaning Shops, Inc., 103 Pa. Super. 66, 157 Atl. 811 (1931). See Reps, Legal and Administrative Aspects of Conditional Zoning Variances and Exceptions, 2 SYRACUSE L. REV. 54 (1950).

32. Pincus v. Powers, 376 Pa. 175, 101 A.2d 914 (1954); Mutual Supply Co. Appeal, $366 \mathrm{~Pa}$. 424, 77 A.2d 612 (1951); Reininger Zoning Case, $362 \mathrm{~Pa}$ 116, 66 A.2d 225 (1949); Jennings' Appeal, 330 Pa. 154, 198 Atl. 621 (1938); Fleming v. Prospect Park Bd. of Adjustment, 318 Pa. 582, 178 At1. 813 (1935).

33. Jennings' Appeal, 330 Pa. 154, 198 Atl. 621 (1938).

34. Dooling's Windy Hill, Inc. v. Springfield Township Zoning Bd. of Adjustment, 371 Pa. 290, 89 A.2d 505 (1952). The Board had refused an exception for the use primarily on the grounds that liquor would be sold on the premises. The Court of Common Pleas reversed the Board, and granted a variance. The Pennsylvania 
influence on the courts is the character of the use for which the variance is requested in relation to the type of district in which it is sought. Thus where a variance was granted for a hotel in a commercial district, ${ }^{35}$ and where a variance was granted for a least restricted use in an industrial district, ${ }^{36}$ the court listed the close relationship between the use and the district as a reason for the variance. On the other hand, where an applicant sought to engage in an industrial occupation in a predominantly residential district, ${ }^{37}$ the court emphasized the disparity between the two uses in sustaining the Board's refusal. The fact that there are other uses of a similar nature in the same district has been held to be unimportant where the court has affirmed a Board's denial, ${ }^{38}$ but this fact also has been listed as a reason for affirming the Board when it granted a variance. ${ }^{39}$ Two other factors which the courts have recognized are the type of building for which the variance is sought and the length of time during which the property has been used for purposes other than those permitted in the district. The extent to which it is recognized again seems to depend on whether or not it is a question of granting or refusing the variance, and the presence or absence of what the court considers to be other more important factors. ${ }^{40}$ In addition, the courts seem to regard with disfavor one who has purchased a property for a use not authorized in the district, since he apparently knew or should have known the consequences of his actions, and therefore has no valid complaint when the variance is refused. ${ }^{41}$ Nor, according to the decisions, should the number of protestants to a proposed variance be considered by the Board in reaching its conclusion. ${ }^{42}$

The courts have decided very few cases where the problem was a deviation from the locational requirements. The considerations seem to be that, if the property is peculiarly suited to a particular purpose for

Supreme Court affirmed the lower court. The other was Lindquist Appeal, 364 $\mathrm{Pa} .561,73$ A.2d 378 (1950). In this case the Board refused the requested variance and the supreme court affirmed the lower court's reversal of the Board.

35. Dooling's Windy Hill, Inc. v. Springfield Township Zoning Bd. of Adjustment, $371 \mathrm{~Pa} .290,89$ A.2d 505 (1952).

36. Triolo v. Exley, 358 Pa. 555, 57 A.2d 878 (1948).

37. Mutual Supply Co. Appeal, 366 Pa. 424, 77 A.2d 612 (1951).

38. Ventresca v. Exley, $358 \mathrm{~Pa} .98,56$ A.2d 210 (1948).

39. Triolo v. Exley, $358 \mathrm{~Pa} .555,57$ A.2d 878 (1948).

40. Compare Dooling's Windy Hill, Inc. v. Springfield Township Zoning Bd. of Adjustment, $371 \mathrm{~Pa} .290,89$ A.2d 505 (1952), and Triolo v. Exley, $358 \mathrm{~Pa} .555,57$ A.2d 878 (1948), with Darling v. Zoning Bd. of Adjustment, $357 \mathrm{~Pa} .428,54$ A..2d 829 (1947).

41. Ventresca v. Exley, 358 Pa. 98, 56 A.2d 210 (1948); Darling v. Zoning Bd. of Adjustment, $357 \mathrm{~Pa}$. 428, 54 A.2d 829 (1947) ; Devereux Foundation, Inc., Zoning Case, 351 Pa. 478, 41 A.2d 744 (1945); McNichol v. Gallagher, 66 Pa. D. \& C. 338 (Montgomery C.P. 1948) ; Cummer v. Narberth Borough Bd. of Adjustment, 59 Pa. D. \& C. 686 (Montgomery C.P. 1947).

42. Lindquist Appeal, $364 \mathrm{~Pa} .561,73$ A.2d 378 (1950); Nugent v. Whitemarsh Township, 68 Montg. Co. L. Rep'r (Pa.) 98 (1952); Reed v. Borough of North Wales, 83 Pa. D. \& C. 69 (Montgomery C.P. 1952); Berg Appeal, 66 Montg. Co. I. Rep'r (Pa.) 194 (1950). 
which it would be impossible to conform to open area or setback requirements, a variance will be granted. ${ }^{43}$ Moreover, if the cost of compliance with the ordinance is entirely out of proportion to the value to be gained by forcing the applicant to conform, the courts are inclined to regard the difficulty as an unnecessary hardship. ${ }^{44}$ In addition to the fact that relatively few setback and area cases have been presented to the courts, most of them have been concerned with requests in the higher classified residential districts, and it seems that economic considerations ${ }^{45}$ were the determining factors, ${ }^{46}$ rather than the prevention of fire hazard or the blocking of light and air, which were the original motivations for the utilization of locational requirements in zoning ordinances. ${ }^{47}$

Since an applicant is not required to prove unnecessary hardship in securing an exception, and since the uses are, in general, of only a slightly more obnoxious nature than the permitted uses, it should be a less difficult task to obtain an exception than a variance. The dearth of cases concerning exceptions seems to support this theory. Where the issue has been presented, the courts have stressed to a greater degree than in variance cases the fact that there were other uses of a similar nature in the immediate neighborhood. ${ }^{48}$

From a perusal of the reported Pennsylvania decisions, it can be seen that very few general rules have been formulated to guide the Board of Adjustment in its consideration of variances and exceptions. Probably, this is due to the fact that, since the cases which have gone to the courts have had such varied factual situations, each case had to be decided independently with regard to the weight to be given individual factors. Moreover, the cases appealed to the courts have been so few in number, when compared to the number of cases handled by the Board of Adjustment, ${ }^{49}$ that the courts have not recognized completely the problems with which the Board is faced. Each municipality has its own particular problems with regard to the types of variances sought, the history and practices of former Boards, and the way in which the locality was previously zoned. The

43. Elkins Park Improvement Ass'n Zoning Case, $361 \mathrm{~Pa} .322,64$ A.2d 783 (1949).

44. Compare Crawford Zoning Case, 358 Pa. 636, 57 A.2d 862 (1948), with Kurman v. Philadelphia Zoning Bd. of Adjustment, 351 Pa. 247, 40 A.2d 381 (1945).

45. E.g., Brodsky v. McShain, 71 Pa. D. \& C. 595 (Philadelphia C.P. 1948).

46. For the effect of surrounding locational variances on the decisions compare Rochelle v. Whitemarsh Township, 69 Montg. Co. L. Rep'r (Pa.) 328, 331 (1953) (variance granted), with Friedman v. Exley, 57 Pa. D. \& C. 586 (Philadelphia (C.P. 1946) (variance refused).

47. See Kerr's Appeal, 294 Pa. 246, 251, 144 Atl. 81, 83 (1928); BassetT, ZoNINg 56 (1st ed. 1936).

48. Philadelphia Fairfax Corp. v. McLaughlin, 336 Pa. 342, 344, 9 A.2d 538, 539 (1939); Jeffrey v. Cheltenham Township, 68 Montg. Co. L. Rep'r (Pa.) 312, 316 (1952); Korylarz v. Zoning Bd. of Adjustment of Clifton Heights, 38 Del. Co. (Pa.) 435, 437 (1950) ; Borden v. Cheltenham Township, 67 Montg. Co. L. Rep'r (Pa.) 72, 77 (1950) ; Cohen -v. Abington Township Zoning Bd. of Adjustment, 43 Pa. D. \& C. 362 (Montgomery C.P. 1941); McConaghy's v. Haverford Township Bd. of Adjustment Ordinance, 31 Dei. Co. (Pa.) 120, 123 (1940).

49. See note 110 infra. 
courts do not even discuss these problems, even though they certainly are reflected in the way in which a Board of Adjustment approaches the consideration of whether or not to grant a variance. In addition, the reviewability of the Board's decision is limited, since the appellate courts generally will reverse the Board's action only for a mistake of law or an abuse of discretion. ${ }^{50}$ The courts have been consistent in refusing to recognize economic hardship alone as a sufficient ground for obtaining a variance. In affirming the granting of a variance or reversing the Board's refusal, the courts seem to require that the property have been used for a similar use in the past, that there be other similar uses in the area, or that the type of use which is sought be closely related to the zoning of the district. However, since most of the cases before the court have been concerned with the Board's refusal, and since in most cases the court has affirmed the Board's decision, ${ }^{51}$ the positive factors which should be present when a variance is granted rarely have been discussed.

After an explanation of the mechanical procedure for obtaining a variance or an exception, an attempt will be made to show the approach taken by the Philadelphia Board in considering variances and exceptions, and some of the particular practical problems with which it is faced.

\section{Procedure Before the Board ${ }^{52}$}

The City of Philadelphia, availing itself of the power granted to it by the state, in 1933 enacted a comprehensive zoning ordinance, ${ }^{53}$ which, except for relatively few changes, ${ }^{54}$ remains in its original form at the present time. The ordinance provides for twenty-two types of zoning

50. E.g., Katzin v. McShain, 371 Pa. 251, 89 A.2d 519 (1952) ; Triolo v. Exley, 358 Pa. 555, 57 A.2d 878 (1948) ; Berman v. Exley, 355 Pa. 415, 50 A.2d 199 (1947).

51. Approximately $85 \%$ of the cases before the supreme court, where the question was whether or not the Board considered the proper factors, were appeals from the refusal of the Board in the first instance. The court affirmed the refusals in about $75 \%$ of the cases.

52. Much of the information in the remainder of the Note was obtained through interviews with the members of the Zoning Division and the Zoning Board of Adjustment.

53. Phuladelphia Zoning Ordinance $\$ 1$ et seq., 1933 Ordinances of the City of Philadelphia 268 (hereinafter cited as Phila. Zoning Ordinance).

54. Primarily, five new residential districts, trailer camp districts and shopping centers have been added since the ordinance was first enacted. PhIzA. ZonING ORDINANCE §6.1, added Dec. 8, 1954; \$9.5, added March 4, 1954; §§ 13.5, 13.6, 13.7,

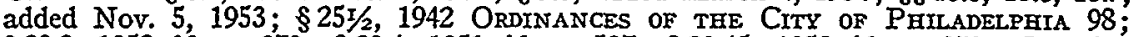
$\S 20.3,1952$ id. at $379 ; \S 20.4,1951$ id. at $527 ; \$ 20.45,1952$ id. at 379 . The industrial district was also subdivided into limited and general by legislative amendment. Phila. Zoning Ordinance \$20.5, 1951 Ordinances of the City of PhillDELPHIA 567; $\$ 20.6,1951 \mathrm{id}$. at $567 ; \S 21$, as amended, $1951 \mathrm{id}$. at 570 . In addition, some sectional changes have been made in an effort to keep pace with changing conditions. For example, open air parking of automobiles in some residential and all commercial zones, the subject of numerous requests before the Board, see text at note 245 infra, is permitted if a Board of Adjustment certificate of exception is obtained. Phila. Zontng Ordinance $\$ 26(6)$, as amended, 1942 Ordinances of the City of Philadelphia 99. 
districts: twelve residential, ${ }^{55}$ four commercial, ${ }^{56}$ an industrial, subdivided into limited and general, ${ }^{57}$ a least restricted, ${ }^{58}$ two shopping center, ${ }^{59}$ a trailer camp ${ }^{60}$ and a park. ${ }^{61}$ Zoning maps, designating the classification of each area on a block-by-block basis, were enacted in conjunction with the substaritive provisions contained in the ordinance. ${ }^{62}$ The ordinance requires a zoning permit to be obtained whenever any type of building is erected, constructed, or altered with respect to height or area. ${ }^{63}$ A use permit is required for every use commenced after the passage of the

55. Phita. Zoning Ordinances $\$ \$ 6-14$, as amended, 1951 Ordinances of the City of Philadelphia 530; Nov. 5, 1953; March 4, 1954; Dec. 8, 1954, Legal Intelligencer, Dec. 9, 1954, vol. 131, p. 709, col. 2. The residential zones are designated alphabetically " $A A$ ", " $A$ ", " $B$ ", "C", " $C-1$ ", " $D$ ", "D-1", " $E$ ", " $F$ ", "H-1", "H-2" and "H-3." The primary uses permitted in the residential zones are detached, semi-detached and attached single family and duplex dwellings, multiple family dwellings, churches, schools and similar uses, and professional offices accessory to the main use. With regard to the type of use, the primary distinctions are that attached dwellings (row houses) are permitted only in " $D$ ", "D-1" and "F" zones, and in "C-1" in groups of not more than ten units, and that multiple dwellings (see note 83 infra) are excluded from "AA", " $\mathrm{A}$ " and " $\mathrm{B}$ " zones. In general, the residential zones are cumulative, that is, all uses that are permitted in the preceding zones are permitted in the next lowest classification. Thus, for example, all uses that are permitted in zones " $A$ ", " $B$ " and " $C$ " are also permitted in zone " $C-1$." Another major difference between the zones is the setback, height, court, side and rear yard, and open area requirements, with, for example, a 35 foot setback being required in an " $A$ " residential zone, while none is required in a "D-1" zone.

56. Phila. Zoning Ordinances $\$ \$ 15-20$. The commercial zones ("A", "B", " $C$ " and "D") provide for local retail and personal service stores, business offices and similar uses. Although there is some difference in the few other kinds of uses permitted in the lower commercial zones (" $B$ ", " $C$ " and " $D$ "), the major difference among all the zones is in the locational requirements.

57. Phila. Zoning Ordinance $\$ \$ 20.5-22$, as amended, 1936 Ordinances of tee City of Philadelphia 166; 1950 id. at 28;1951 id. at 567-70; Sept. 9, 1953. The limited industrial district is, in general, restricted to light manufacturing, warehousing and storage, while what would be considered heavy manufacturing, such as aircraft manufacturing and assembling, or more obnoxious uses, such as brewing and distilling, are relegated to the general industrial district. There is also a wide divergency between the two districts in the height and open area limitations. In the general industrial district, residential and similar uses are prohibited.

58. Phila Zoning Ordinance $\$ 23-24$, as amended, 1936 Ordinances of the City of Priladelphia 166; 1950 id. at 28; 1951 id. at 570 ; Sept. 9, 1953. The uses most detrimental to the health and safety of surrounding property owners are placed in the least restricted district, for example, abattoirs, the storage of explosives, the manufacturing of industrial poisons and chemicals, and garbage or dead animal reduction. As in the general industrial district, residential and related uses are specifically prohibited.

59. Phila. Zoning Ordinance $\$ \$ 20.3-.45$, added by 1951 Ordinances of the City of Philadeiphia $527 ; 1952$ id. at 379.

60. Phila. Zoning Ordinance $\$ 25 \frac{1}{2}$, added by 1942 Ordinances of the City of Philladelphia 98.

61. Phila. Zoning Ordinance $\S 25$. For a graphic description of the requirements of the various zones see Peiladelphia Zoning Ordinance Districts, Citizens' Council on City Planning (1954).

62. This does not mean that each block is zoned differently from the blocks on either side of it, but merely that each block is designated separately on the zoning maps. However, primarily in the older sections of the city, one block may have as many as three zones in it. This is due not only to the various types of uses and structures that existed before the passage of the ordinance but also to the number of zoning map changes made by the City Council since that time.

63. Phila. Zoning Ordinance $\$ 29(1 ;$. 
ordinance. $^{64}$ In addition, whenever a building is erected, or altered with respect to height or area, or a change in the class of use is desired, a use permit must also be secured, although single family and duplex dwellings and places of worship are excepted from this provision. ${ }^{65}$

The procedure for obtaining a variance or exception ${ }^{66}$ is begun with a request for a permit in the Zoning Division of the Department of Licenses and Inspections. ${ }^{67}$ If the proposed use or construction does not conform to the ordinance requirements, the permit will be denied, but the applicant is entitled to appeal to the Board of Adjustment to secure a variance. ${ }^{68}$ Approximately fifteen thousand requests are made each year for zoning and/or use permits, with about nine thousand eventually being processed administratively. ${ }^{69}$ From twenty-five hundred to three thousand requests ${ }^{70}$ usually are refused in the first instance, and approximately ninety-five per cent of these are appealed to the Board. Appeals must be filed within thirty days from the time when the Division refused to grant the permit, unless a majority of the Board permits the appeal to be filed at a later date. ${ }^{11}$ The appeal form which is provided for variances is in most cases merely an administrative record, and is not used by the Board in its consideration of the case, although a space is provided for stating what the applicant considers to be the unnecessary hardship. Subsequent to the filing of the appeal, the applicant is required to post the premises for twelve consecutive days prior to the date of the hearing, stating the date, time, place and purpose of the hearing. ${ }^{2}$ The posting of the notice is a prerequisite to obtaining a hearing and, if the applicant has not complied, a re-posting will be required. The notice is examined on two separate

64. Phila. Zoning Ordinance $\$ 29(2)$.

65. Ibid.

66. See note 68 infra.

67. See note 11 supra.

68. Technically, an exception is not an appeal, since the Board has original jurisdiction to decide when it should be granted. See text preceding note 13 supra. However, an application is filed in the Zoning Division which is then referred to the Board of Adjustment, and for all practical purposes they are handled the same way administratively as variances.

69. The other 6,000 request changes for which permits are not required, for example, interior alterations to structures.

70. These figures include from 600 to 800 exceptions.

71. Rules of Procedure, The Zoning Board of Adjustment of the City of Phinadetphia Rule 2. The Rules were adopted in accordance with the ordinance which provides for the adoption of rules governing the procedure to be followed in securing an appeal. See Phil A. Zoning Ordinance \$31(4).

72. Rules of Procedure, The Zoning Board of Adjustament of the City of Philadelphia Rule 3. The posters are large enough to be seen by anyone interested in the proposed use, and there were very few postponements because of the failure to post the premises. Moreover, generally the complaint was not that the poster itself was inadequate, but that the applicant had posted it in an inconspicuous place. However, in a few cases where the construction of a building was involved, the protestants appeared primarily to find out on what portion of the lot the structure was being built, and not to contest the variance. In most cases, the applicant did not know whether the poster was adequate until he saw whether or not protestants appeared at the hearing. 
occasions ${ }^{73}$ and the reports are incorporated into the file. which is before the Board during the hearing.

The primary difficulty in the administration of the ordinance is the apparent ignorance of the zoning laws by a majority of the citizens and the lack of an adequate enforcement staff. A large number of those applying for permits either are referred or reported to the Zoning Division by other city administrative offices. ${ }^{74}$ The lack of adequate enforcement facilities also is reflected in the cases which are handled by the Board of Adjustment. In many of the requests for use variances and exceptions, the use sought is already existing in violation ${ }^{75}$ of the ordinance and has been in operation for from one to ten years. ${ }^{76}$ Since it has only two inspectors to enforce the ordinance in the entire city, the Zoning Division works on a complaint basis, which would seem to be the only feasible method of enforcement with such a limited staff. If a violation is reported, the property is inspected, and if the complaint is accurate the violator is given ten days either to desist from the illegal operation without punishment 77 or to appeal to the Board. However, if the applicant elects to appeal to the Board and the variance is refused, he is subject to the penalty provided for by the ordinance. ${ }^{78}$ Stricter enforcement of the ordinance probably would be engendered by imposing the sanction even if the violator ceases using the property illegally or secures a variance on appeal to the Board. Under the present situation, a wilful violator might be able to operate a use illegally with the tacit consent of his neighbors,

73. The Zoning Division has four inspectors, two of whom are concerned with complaints, see text following note 76 infra, while the remaining two are engaged in preparing cases for the public hearing. The latter two, who divide the cases between them, examine the notice while making a report of the block in which the variance is sought. See text at note 91 infra. Because of the number of complaints that had been received about improper posting, the aid of the Police Department was also enlisted. A short form stating whether or not the property has been posted is received in each case from the police officer on whose patrol the property is situated.

74. For example, most of those violating the multiple dwelling provisions of the ordinance are reported by the Division of Housing and Sanitation.

75. See tables 2 and 4 infra.

76. An example of how some of the uses existing in violation are detected was presented in a case in which the applicant requested a building permit to extend the first floor of a funeral parlor. When the records were examined, it was discovered that the property was not zoned for a funeral parlor. The applicant explained that in 1942 he had been granted a temporary non-conforming use for the period of one year (a use granted by the Board benefiting the health or welfare or promoting the development of the district which may not exceed the period of one year, Phina. Zoning Ordinance \$ 4(8)), and that on its expiration he was told by his ward leader that the property would be re-zoned or that a variance would be granted so that he could continue in business. The Board legalized the use, but denied the requests for the addition since it would have extended beyond the properties on either side.

77. See note 78 infra.

78. The ordinance provides that any person who constructs or uses any land or building without complying with the provisions is subject to a fine, PHILA. ZonIng ORDINANCE $\$ \$ 30(1)-(3)$, and the Zoning Division's policy has been to fine only those who refuse to discontinue the use, or who are unsuccessful on the appeal to the Board. The violator is subject to a fine of not more than $\$ 1000$ and not less than $\$ 100$, ibid.; but the usual penalty assessed is $\$ 100$. 
and, if and when he is detected, he either could utilize the period of illegal use as an arguing point for being granted a variance, ${ }^{79}$ or desist from the illegal use without fear of the imposition of the ordinance's sanction. However, the present procedure undoubtedly is based on the theory that a majority of those violating the ordinance are doing so innocently, and that, if conditions exist which warrant the granting of a variance, it would be unfair to punish the violator for his failure to apply at an earlier date.

The public hearing, ${ }^{80}$ which is divided into morning and afternoon sessions, is held once each week. On an average day, the Board hears from sixty to seventy cases. Although in most instances the Board spends only from three to five minutes in hearing a case, when a large number of protestants are present the proceeding may take over half an hour. ${ }^{81}$ Each applicant is required to submit a deed or lease indicating his interest in the property, two photographs, one of the front and one of the rear, showing the posting of the zoning notice, and, if any construction or alteration is involved, a detailed plan or blueprint of the proposed building and its location on the property. ${ }^{82}$ When the proposed use is a multiple dwelling containing three or more housekeeping or non-housekeeping apartments, ${ }^{83}$ a blueprint, drawn to scale and showing the dimensions and area of each room, is also required. ${ }^{84}$ An applicant is not necessarily

79. See note 76 supra and text following note 142 infra.

80. Both the enabling act, note 21 supra, and the ordinance require a public hearing. Phila. Zoning Ordinance § $31(6)$.

81. Although a docket listing the order in which the cases will be heard is provided each week, the fact that the time spent on a particular case depends on the type of variance and the presence or absence of protestants makes it difficult to ascertain the exact time at which a case will be heard, and at times results in rather bitter complaints on the part of applicants and their attorneys. The Board in most instances, however, follows the docket, and does not hear cases out of order.

82. Rules of Procedure, The Zoning Board of Adjustment of the City of Philadelphia Rule 7.

83. A multiple dwelling, permitted in all residential zones except "AA," " $A$ " and " $B$ " and in all commercial zones, is defined as a dwelling occupied by three or more families, each living independently of the other. A family is merely defined as a person, or a group of persons living together. PHILA. Zoning ORdinance $\$ 2(6)(f)$, $2(7)$. In Philadelphia, the majority of multiple-dwelling cases are concerned with the conversion of single-family dwellings or the legalization of existing multiple dwellings in districts in which they are permitted, but require a variance because they are deficient in locational requirements. However, a use variance rather than a zoning variance is required, since no construction or physical alteration is involved. See text following note 17 supra. As an illustration, both single-family and multiple dwellings are permitted in "D" residential zones. However, a single-family dwelling requires a rear yard area of 144 square feet, while a three-family multiple dwelling requires a rear yard area of 344 square feet. Moreover, an additional 100 square feet of rear yard area is required for every family over three. Consequently, although a property may have a sufficient rear yard area for a single-family dwelling, a use variance may be required if a conversion is made to three or more families. PhILA. ZonINg ORDINANCE \$10(12). In addition, the Board further differentiates between housekeeping and non-housekeeping units in its treatment of multiple dwellings. A housekeeping unit is what is commonly referred to as an apartment, while a non-housekeeping unit is the use of a single room, as for example, in the case of boarding houses. Practically all of the multiple-dwelling cases, however, involved housekeeping rather than non-housekeeping units.

84. Rules of Procedure, The Zoning Board of Adjustarent of the City of Philladelphia Rule 7. 
precluded from arguing his case on the date set for the hearing, even though he has neglected to supply some of the required documents. In most instances he is permitted to present his case, but the decision is reserved until the omitted paper is filed. However, if he has not provided any of the required documents, the hearing is postponed. ${ }^{85}$

All proceedings before the Board are recorded by a stenographer, but this record is transcribed only if an appeal is taken to the court. The members of the Board rely on their notes taken during the hearing in making their decisions. ${ }^{86}$ The testimony of applicants and protestants ordinarily is not required to be given under oath, ${ }^{87}$ except in the case of proving non-conforming uses. ${ }^{88}$ In most cases, the applicant himself first presents his case to the Board orally in a very informal manner; then, if there are any protestants, they are permitted to state their objections. The presence or absence of unnecessary hardship is elicited more by the Board in its questioning of the applicant, than by his presentation. Since the Board has determined in advance when certain factors will automatically render the case an unnecessary hardship, or preclude further consideration, ${ }^{89}$ if the particular case falls within one of these categories the most rapid manner of disposing of the case is by direct questioning. In addition, although the applicant has the burden of proving that he is entitled to the variance, it seems that a large number of applicants have no conception of what the term unnecessary hardship implies and, therefore, the only manner in which the necessary proof can be adduced is through the Board's questioning. However, an increasing number of cases are now being argued by attorneys and some of them, particularly those who handle cases every week and who have a knowledge of the standards followed by the Board, are more detailed in their presentation, submitting photographs of the surrounding area and formal pleadings listing what they consider to be the facts constituting the hardship.

In addition to the documents required to be filed at the hearing, and whatever additional evidence the applicant submits, the Board has

85. Generally, when a use question was involved, the hearing was also postponed if the applicant did not have any photographs. Usually, however, if the applicant failed to submit the photographs, he did not have any of the other required documents.

86. All the members of the Board were present at most of the hearings during the period in which this study was made. However, if a member was absent, he did not vote on the cases heard during his absence.

87. The Board, by a vote of two members, may require any statement of fact to be made under oath. Rules of Procedure, The Zoning Board of Adjustment of THE City of Philadelphia Rule 8.

88. Under the ordinance a non-conforming use is permitted to continue in existence indefinitely, and to increase an additional $25 \%$. Prila. Zoning Ordinance $\$ \$ 4(1), 4(2), 4(6)$, as amended, 1950 Ordinances of THE City of PhiladelpHia 27. In a few cases, where no record of the non-conformance of the use existed in the Zoning Division, the applicant applied for a variance and was permitted to prove at the hearing by the testimony of witnesses who had a direct knowledge of the use of the property, that the use had been continually in existence since before the passage of the ordinance.

89. See text following note 113 infra. 
the file of the case containing the type of variance sought, the reason for its initial refusal by the Zoning Division, the original application, the appeal form prepared by the applicant listing the reasons for the hardship, any communication the Board has received, either in behalf of or opposed to the variance, the police report of whether or not the property has been properly posted ${ }^{20}$ and an inspector's report. The inspector's report, in addition to stating whether or not the property has been properly posted, contains a description of the use and general area dimensions of the various properties on each side of the street of the particular block in which the variance is sought. ${ }^{.1}$ Although it is generally admitted that a personal inspection of the premises by the members of the Board would be the desideratum, the number of cases which are handled each week and the limited amount of time which the members of the Board have to devote to handling variances make it impossible. However, in a number of cases, the standards adopted by the Board obviate the necessity of an inspection by a Board member, and in some particularly close cases a personal visit will be made by at least one member. ${ }^{92}$ In all other cases, the members of the Board must rely on the inspector's report, their own knowledge of the city, the photographs, and the often conflicting testimony of applicants and protestants.

A majority of the cases are decided on the day of the hearing or on the following day, and the applicant usually is informed of the result within a week. The Board, except in those cases which are appealed to the courts, does not make any findings of fact or give any reasons for its decision, but, instead, it notifies the applicant of the grant or refusal of the variance on a standard form..$^{93}$ If a variance is granted, the use must be commenced within one year after the Board's authorization, ${ }^{94}$ and, if it is not, the applicant must file a new appeal. If a variance is refused, the applicant is precluded from seeking another variance for the same property for the period of one year, unless a re-hearing is granted by the vote of three members of the Board because of new conditions which arose since the previous hearing. ${ }^{95}$

\section{Cases Before the Board}

During the nine-week period ${ }^{96}$ in which this study was made, over 569 cases came before the Board. About thirty-five per cent ${ }^{97}$ of the cases

90. See note 72 supra.

91. The report is given to the Board members three days before the hearing. Previously, the report also contained a recommendation by the inspector as to the disposition of the case, but the practice was discontinued by the present Board because of a possible prejudicial effect on its decision.

92. Usually, an official visit by a Board member is made in three or four cases a week, after the hearings on the particular cases have taken place.

93. Protestants are also notified of the result of the Board's action.

94. Rules of Procedure, The Zoning BoARd of Adjustment of the City of Philadelphia Rule 13(b).

95. Id. Rule 11 .

96. From July 13, 1954, through Sept. 10, 1954.

97. 198 cases, or $34.8 \%$, were concerned with variances for multiple dwellings. 
involved requests for multiple dwellings in districts in which they were permitted, ${ }^{98}$ but use variances were needed because the properties did not meet the locational requirements. ${ }^{99}$ The second largest class, comprising about thirty per cent ${ }^{100}$ of the total number of cases, involved requests for use variances ${ }^{101}$ and use and zoning variances, ${ }^{102}$ and, for the most part, these cases were concerned with the introduction of a use into a district for the first time, or the legalization of an existing use. ${ }^{103}$ A slightly higher percentage of the cases in this group was comprised of requests for commercial, ${ }^{104}$ rather than industrial, ${ }^{105}$ variances. About fourteen per cent ${ }^{106}$ of the cases involved exceptions, and about sixteen per cent ${ }^{107}$ involved residential ${ }^{108}$ or commercial zoning variances, where no use question existed.109 The number and types of cases which were argued before the Board during this period seemed about normal when compared to the two previous years. ${ }^{110}$

Use variances ${ }^{111}$ will be discussed first, not because they represent the primary problem in Philadelphia, but because of the more varied factual situations which they present. An attempt will be made to deter-

98. Six requests for the conversion of single-family dwellings into two-family dwellings in districts in which only the former were permitted " $A$ " and " $B$ " residential) were included in the 198 cases. They represent a different problem than that presented in the multiple-dweiling cases, note 112 infra, but, since there were not sufficient cases to draw any definite conclusions, for convenience they will be treated with the multiple-dwelling group. See note 216 infra.

99. See note 83 supra.

100. 160 cases, or $28.1 \%$, involved use or use and zoning variances. However, seven of these cases were concerned with proving non-conforming uses, note 88 supra, leaving a total of 153.

101. 115 cases involved use variances.

102. 38 cases involved requests for both use and zoning variances.

103. See note 113 infra.

104. 86 of the 153 cases, or $56.2 \%$.

105. When used in this Note, an industrial use will refer to any use permitted in the limited or general industrial district and the least restricted district. See notes 57,58 supra. Specific references will be made, however, to different types of uses in the industrial classification in the discussion of the various factors.

106. Certificates of exception were sought in 80 cases, or $14.1 \%$. Two of the cases were concerned with proving non-conforming uses, note 88 supra, leaving a total of 78.

107. In 94 cases, or $16.5 \%$, there were requests for zoning variances but no requests for use variances. erties.

108. 59 of the zoning variances, or $56.7 \%$, were -requested for residential prop-

109. 37 cases, or $6.5 \%$ of the total number of cases, are not included in any of the aforementioned groups. These cases will not be treated in this Note either because there was not a sufficient number of cases of one type to draw definite conclusions, or it was felt that they did not represent a significant type of case: These cases required either use or use and zoning variances, although generally the variance did not represent a significant change in use. For example, most of the cases were concerned with obtaining variances for non-accessory general advertising signs, non-housekeeping units in multiple dwellings, note 83 supra, or construction of buildings in park districts.

110. See Analysis of Zoning and Use Vartances 1952-53, Cittzens' Counctl on Crty Planning (1954). This was substantiated by one of the Board members. 113 infra.

111. Some use and zoning cases will also be included in this group. See note 
mine the influence that certain general factors have on the Board's decisions and to examine particular considerations which may arise in individual cases. The conditions that usually are required with regard to multiple dwellings, ${ }^{112}$ zoning variances, and exceptions will then be discussed briefly.

\section{Use Variances ${ }^{113}$}

No Similar Uses in the Block.114_The Board, in determining whether or not to grant a variance, normally considers only the effect that it would have on the other properties in the same block, on the theory that the effect usually does not extend any farther. If the block is divided into two zones, the Board will consider only the effect of the variance on the properties in the particular zone of the block in which the applicant's property is situated. ${ }^{115}$ During this study, a large number of variances were requested in blocks where no similar uses existed. Practically all of the variances sought in this classification were for "standard commercial uses," such as beauty shops, barber shops and grocery stores, in residential neighborhoods. ${ }^{116}$ Rarely was a request made to convert a residential

112. Although use variances are required for multiple dwellings, note 83 supra, they will be treated separately for three reasons. First, the problem is not the intrusion of a prohibited use into a higher classified district as in the case of other use variances, but rather the increasing density of population of an area, in relation to the locational requirements of the ordinance occasioned by a permitted use. Secondly, the conditions for obtaining a variance for multiple dwellings were practically the same in all cases; and, finally, they represented a large percentage of the cases before the Board in comparison to the other types of variances requested.

113. Of the 160 use and use and zoning cases, excluding the seven non-conforming uses, note 100 supra, 115 concerned use variances and 38 involved requests for both use and zoning variances. Nine of the cases were either withdrawn or refused because the applicant did not appear at the hearing, and decisions were not available for eight, leaving 102 use, and 34 use and zoning, cases. Of the 34 use and zoning cases, 19 will be included in this section because they were concerned with the establishment of the particular use for the first time or the legalization of an existing use. Consequently, in those cases in which variances were refused, it appeared that the use of the property was the reason for the refusal of both the use and the zoning variances, since the refusal of the use variance would also require the refusal of the zoning variance. However, even in those cases where the use and zoning variances were granted, since it represented the legal existence of the use in the district for the first time, it appeared that the use variance was more significant than the zoning variance, although the requirements that the Board considers controlling with respect to the location of the building on the property also had to be met. See, e.g., the case discussed in note 76 supra, and the text at notes 230-31 infra. The remaining 15 use and zoning cases will be treated in the section dealing with zoning variances. See text following note 226 infra. Therefore, this section of the Note will deal with 102 use and 19 use and zoning cases.

114. 35 use and three use and zoning variances were sought in this group. See table 1 infra.

115. For example, in one case a block was divided by a small street with part of the block zoned commercial while the remaining portion was zoned residential. The Board, in refusing to grant the variance, was quite emphatic in advising the attorney who was arguing the case to refrain from citing the nine commercial uses in the commercial zone as a reason for granting a variance in the residential zone.

116. Of the total of 38 cases in this group, 33 requests were made for commercial uses in residential zones. See table 1 infra. 
property into an industrial use, ${ }^{117}$ or to build an industrial plant in a completely residential block..$^{118}$

Most of the applicants requesting a commercial variance did so on the ground that there were other commercial uses "in the area." An applicant often contended that he was entitled to a variance because there was a commercial use one, two or three blocks from his property, or that there was one in a commercially zoned district in the same block as the residential district where his property was located, or on a corner property in the same block. Normally, the Board would not grant a variance on the basis of either of the first two grounds because of the absence of a commercial use in the applicant's block or in his zone of the block; and, similarly, the Board usually would refuse an application based on the third ground because it is the policy of the Board not to take into account the existing use of a corner property when considering a variance for a property in the middle of the block. Many applicants also contended that there was a need for the particular use in the area. The applicant actually was seeking a virtual economic monopoly, since it can be assumed that if the district is an unbroken residential one, there naturally would be a need so far as proximity to the nearest similar commercial use is concerned. In general, the Board would not permit this need to override the policy of not breaking the block, even if it was confronted with petitions favoring the proposed use. ${ }^{119}$ Moreover, in most of the cases in this classification, the hardship was one personal to the applicant, such as financial need or inability to secure another property in which to carry on his business. In very few cases was the claim made that the property was not suited for the purpose for which it was zoned. Nor did the fact that the property was situated on a corner, which seemed to be a significant factor in other classifications, ${ }^{120}$ have any favorable effect, so far as the applicant was concerned, on the Board's decision. ${ }^{121}$ In about 72 per cent of the cases

117. In the three cases in which this was attempted, the uses were already existing in violation of the ordinance, and as would be expected, were protested, and refused. See table 1 infra.

118. There were two cases in this category, but in only one was a zoning variance involved. The argument presented in one case was that the area was degraded and that consequently no one would build for residential purposes, and that there were two other industrial uses in the next block. In the other, the applicant contended that the Board had granted a variance for the same type of use (garage for the storage of trucks and cement contractor's equipment permitted in the general industrial district) for a property only a short distance away. However, that use was adjacent to the rear of the properties and was located in a commercial zone, while the proposed use would have faced the residential properties. Both uses were protested, and the variance was refused in both instances. See table 1 infra.

119. Petitions favoring, or denoting no objection to the use were presented in about five of these cases. In three, the use was refused, and in two, home occupation type variances, see text at note 123 infra, were granted. In two of those refused, and in one in which a home occupation was granted, protestants also appeared to contest the use. In only one, the case in which the home occupation was granted and protested, did those favoring the use appear at the hearing. See note 187 infra.

120. E.g., see text preceding note 134 infra.

121. Eight of the properties were located on corners; in only one was a variance granted, and that was for a home occupation. See text at note 123 infra. 
in this group in which commercial variances were sought in residential districts, the variance was refused. ${ }^{122}$

However, in a few cases, in spite of the fact that no commercial uses existed in the block, the Board granted limited-type variances. The first of the two types of variances that were granted was termed a home occupation. ${ }^{123}$ The limitations imposed were that the applicant perform all of the work himself, that there would be no advertising, and that no exterior alterations would be made to the building. ${ }^{124}$ Only certain types of uses can be conducted in such a limited manner, as, for example, a beauty shop. ${ }^{125}$ In the cases in which a home occupation was granted, the Board apparently considered the particular pressing economic need of the applicant and, in some, the proximity of the property to a commercial district, combined with the slight chance of there being any increased traffic or noise, because of the rigid restrictions placed on the use. In the second type of case certain plumbers were required by an ordinance to maintain offices in order to receive permits and were required to display exterior signs. ${ }^{126}$ The applicants sought to use their private residences for these purposes, and in practically all of the cases the variances were granted, apparently on the theory that the harm to the particular neighborhood was far outweighed by the economic hardship to the applicant if he were required to obtain an office for these limited purposes. ${ }^{127}$ In addition, this type of variance was very limited since it expressly stated that the property could not be used for the storage of supplies and that the sign must be flush against the building and of a certain size. Outside of these relatively few exceptions, ${ }^{128}$ the Board was quite adamant in enforcing the general rule, when no factors other than those mentioned were present, ${ }^{129}$

122. 24 of the 33 commercial variances requested, or $72.7 \%$, were refused. See table 1 infra. Of the two commercial use and zoning variances sought, both would have extended a good deal beyond the properties on either side of them, presenting a twofold reason for their refusal. See text following note 230 infra.

123. Four variances of this type were granted.

124. The official language used is: "That the applicant shall reside in the premises and perform the work him(her) self; that no employees shall be engaged to assist in the work; that no advertising of the business shall be done either by signs appearing on the premises, or by telephone directory or pamphlet; also that there shall be no objectionable noise." Some of these conditions would seem to be attached to the particular applicant rather than to the property itself. See text following note 16 supra.

125. Two of the four home occupation variances granted in this group were for beauty shops.

126. Five of these cases were heard by the Board.

127. Four of the five were granted. One of the variances was protested, and it was the variance which was refused. The primary concern of the Board seemed to be that the applicant also would use the premises for the storage of materials, and this may have been the reason for the single refusal.

128. In this group, the remaining variance that was granted was for a basement office for an association of neighbors to receive mail and other communications. The use had existed in violation for three years and was not protested.

129. See text following note 140 infra. 
ignoring in particular the economic divergencies inherent in the various zoning districts. ${ }^{130}$

Number of Similar Uses in the Block. ${ }^{131}$-One of the factors which appeared to influence the Board to grant a variance was the existence in the block of a number of uses similar to the one which the applicant requested. It would seem to be a rather anomalous situation when a block which is zoned residential or commercial contains a number of commercial or industrial uses, or a commercially-zoned block, several industrial uses. Although this condition is partially attributable to the existence of nonconforming uses at the time of the adoption of the ordinance, it is due primarily to the numerous zoning map changes made by City Council and the indiscriminate granting of variances in past years.

As in the cases where no similar uses existed in the block, the typical kind of variance which was sought was for a commercial use; ${ }^{\mathbf{1 3 2}}$ however, in this classification almost all of the variances were granted..$^{133}$ For example, where a variance was requested for an accounting office in a block that was zoned residential, and the only showing of hardship was that approximately five other similar or lower-type uses, exclusive of corner properties, existed in the block, a variance was granted. However, even in these cases, if the block still retained strong residential characteristics the Board imposed some restrictions on the variance. Thus, in two cases the Board limited the conduct of the business to the first floor and required that all signs be flush against the building. The policy of granting a variance if there are other similar uses also was applied to corner properties, although probably with more justification. For example, if two of the four corners already are being used commercially, the application for the use of the third for a commercial purpose probably will be granted. Although again the claim usually was not made that the property could not be used for the purposes for which it was zoned, ${ }^{134}$ the applicant had a strong argument that a high percentage of the persons in the block who were in a situation similar to his had an added economic advantage; that, because of the presence of the other uses, the conversion of his property would have virtually no effect on the neighborhood; and that, due to the limited area involved, i.es, the four corners, the Board could not be accused of either changing the zoning of a particular block or providing an arguable case ${ }^{135}$ for future variances.

130. In this classification, only nine of the 35 requests for use variances were granted, and all of these were of a limited nature. All three of the use and zoning variances were refused. See table 1 infra.

131. Ten use and four use and zoning variances were requested in this classification. See table 1 infra.

132. In this group, nine of the 14 cases involved commercial variances. See table 1 infra.

133. Eight of the requests for commercial variances were granted, and one was refused. See table 1 infra.

134. See text following note 119 supra.

135. Although the other three would certainly serve as an arguing point for the fourth corner, there is no comparison between that situation and the situation where there are only three or four commercial uses in the middle of a block which is comprised of from 15 to 20 properties. 
The Board applied the same policy to the two cases in which variances for industrial uses were requested in blocks which contained other industrial uses and which were residentially zoned, although they contained no residences. ${ }^{138}$ In general, when an industrial use is requested, the Board will inquire into the type of use in greater detail than in the consideration of a commercial variance. For example, if a variance is sought for manufacturing a particular kind of article, the applicant is usually required to explain the type of machinery used, the adequacy of the facilities for loading and unloading, and the type of use on either side of the property. However, since in this classification there usually were at least three other similar uses in the block, these considerations did not often result in the refusal of the variance. ${ }^{137}$

Thus, the problem of both the commercial and industrial variance in this group is whether the Board should ignore the theoretical zoning of the block and concern itself only with the practical situation, or whether, when the zoning of the block becomes so unrelated to the existing uses, the proper remedy should be an immediate area change by City Council, rather than through a gradual change by the Board. In most cases, the Board seemed to take the practical approach and granted the variance. ${ }^{138}$

Previous History ${ }^{139}$ and Present Structure of the Building. ${ }^{140}$-Another factor which seemed to influence the Board in deciding whether or not to grant a variance was the use which had been made of the property in the past. Usually when a property has been used for a commercial purpose in the past, the building has a store front; therefore, it is particularly adapted for a commercial use. ${ }^{141}$ Moreover, so far as the history of the property is concerned, even though the Board did not consider other uses existing in the block in violation of the ordinance as grounds for granting a variance in a particular case, the fact that the use sought had been existing illegally for a number of years did not necessarily preclude

136. In both cases the variance was granted.

137. In this group, four of the five requests for industrial variances were granted. See table 1 infra.

138. Of the ten use cases in this group, nine variances were granted and one was refused. Three use and zoning variances were granted and one refused. See table 1 infra.

139. When used in this Note, "previous history" generally will refer either to the former legal use of a property for a different use from that which is requested by the applicant or, in a few cases, to the former illegal use of the property for the same use for which the variance was requested. In the latter cases the illegal use had existed on the premises for at least five years. All of these cases are discussed together since both situations are similar so far as the actual establishment of a use in a district and the reaction of the neighboring property owners to it are concerned.

140. 15 use and three use and zoning cases were included in this group. See table 1 infra.

141. Six of the seven commercial variances requested in this group were for properties which had commercial-type buildings. 
the granting of the variance and sometimes served as a factor in its favor. ${ }^{142}$ In one case, the applicant purchased a corner property with a store front from a builder who had not obtained the necessary zoning permit. Although the property was located in a residential district, the applicant apparently believed that the property was properly zoned and operated a store for a number of years. Later, he wanted to sell the property for commercial purposes. The Board granted the variance probably because the property was commercially designed, did not visibly interfere with the residences in the block since it was a corner property, with the store front facing on only one street, ${ }^{143}$ had existed for a number of years without provoking any complaints from neighboring property owners, and substantial investments had been made in installing commercial equipment in the building. Even though there were no other commercial uses in the block, the general policy of the Board seemed to be to grant a variance, if the property, usually on a corner, ${ }^{144}$ had been used commercially for a number of years, was constructed for a commercial purpose, and the residents of the neighborhood showed no repugnance ${ }^{145}$ to its continued use. $^{146}$

The Board followed a similar policy when it considered industrial uses, ${ }^{147}$ even though they were located in residential districts, ${ }^{148}$ or had been existing in violation for a number of years. ${ }^{140}$ As in the case of commercial variances, the present construction of the building was an important factor, since usually the building was unsuited for any use other than an industrial-type use. ${ }^{150}$ So far as economic considerations are

142. Three of the commercial properties were existing in violation, while in another the applicant ceased using the property illegally about three months before the request for a variance was made. All the uses existing in violation in the commercial classification were conducted in commercially designed properties, and in each case the variance was granted. See table 2 infra.

143. The practice of many builders in recent years has been to place the store front on the side of the property located at the end of a row, and, consequently, the store front will face only one street.

144. In this group, four of the properties for which commercial variances were sought were located on corners. Three of the four were granted variances. 3 infra.

145. None of the commercial variances in this group were protested. See table

146. All five commercial use variances in this group were granted, although one of those granted was for a home occupation. In the two cases in which both use and zoning variances were requested, the zoning variance was refused, although in one case the Board granted a use variance, legalizing an existing use. See table 1 infra.

147. In this group there were ten cases in which industrial use variances were sought and one in which both an industrial use and zoning variance were requested. See table 1 infra.

148. Three of the uses were sought in residential zones, while four others were sought in "A Commercial" zones which either were surrounded by, across the street from, or directly behind, residential zones. All three properties located in residential zones were granted variances. Of the four properties in close proximity to a residential zone, two were granted and two were refused.

149. Of the seven industrial uses existing in violation, three were granted variances and four were refused. See table 2 infra. However, the illegal use was the only history that three of the four uses refused had. See note 139 supra.

150. Five of the properties were particularly suited for the uses which were requested because of the construction of the building. Variances were granted for four of the five properties. 
involved, the industrial-type case in a residential block presents a more compelling reason for granting a variance than the commercial-type case, since generally the building is completely unsuitable for residential purposes and the only course that would be left open to the applicant would be to sell the land itself for a residence or for other conforming uses. In addition, most of the industrial buildings had been constructed and in use before the passage of the ordinance, but had lost their legal status as nonconforming uses by discontinuance or change of use. ${ }^{151}$ Although one of the basic conflicts in the question of deviation from the zoning ordinance is between the desire to have all properties in a block conform to the zoning requirements and the economic hardship that would be imposed upon the applicant if he were deprived of the most profitable, and in some cases any, use of the building, this conflict is carried to its extremity in the request for an industrial variance in a residential zone when the property has been used for an industrial purpose in the past and the building is peculiarly suited for an industrial use. In the majority of the cases in which the issue arose, the Board seemed impressed by the economic hardship of the applicants, and granted the variances..$^{152}$ Thus, where a factory-type building in a residential block had been used as a dairy since before the passage of the ordinance and for approximately a year the owner had been unable to sell or to rent the premises, a variance was granted for a similar use..$^{153}$ However, the fact that the property had an industrial history and was particularly suited for industrial purposes will not guarantee automatically the granting of a variance. Generally when a variance was granted, in addition to the past history and present structure of the building, the requested use was of the same class, or of a higher class than the use that was formerly on the property. In a few cases, other factors, such as the nature of surrounding uses and the adequacy of the existing facilities for engaging in the type of use sought, overrode the considerations of history and construction. For example, a variance was refused where a property, which was zoned "A Commercial" and previously had been used legally for a warehouse, had been vacant for about a year, and, at the time of the application, was being used illegally for the same purpose. The property was next to a school and across a narrow street from a residential block, and probably the safety of the residents was considered to be more important than the hardship to the applicant.

In most cases, however, whether a commercial or an industrial use was sought, the fact that the property had been used similarly in the past

151. See text at notes 28,29 supra. According to the applicants, about five of the buildings had been used for non-conforming uses, two of them being in residentially zoned districts. All five were granted variances.

152. In this group, six of the industrial-type uses were granted, three were refused, and a temporary non-conforming use was granted in one case. The one request for both a use and zoning variance was refused. See table 1 infra.

153. The variance was granted for the freezing, packaging and distribution of frozen foods. Both uses are permitted in the limited industrial classification. 
and was particularly suited for the type of use requested seemed to be a very persuasive factor in influencing the Board to grant the variance. ${ }^{154}$

Number of Similar Uses and Past History. ${ }^{155}$ - Since the Board appeared to grant some variances either because of similar uses in the block or because of the past use of the property and the present character of the building, the applicant had an even better chance of obtaining a variance if he could prove that both factors were present in his case.

In this group, many of the commercial variances ${ }^{150}$ were sought for corner properties when two or three of the other corners were being used commercially. ${ }^{157}$ All of the commercial variances were sought in blocks which were zoned residential, again raising the propriety of the Board's policy with regard to a change in zone, ${ }^{158}$ although the added fact of past use and building construction ${ }^{159}$ is possibly a distinguishing factor. ${ }^{160}$ The Board granted all of the requests for commercial variances in this classification, ${ }^{161}$ but conditions were imposed in two of the cases.

Although most of the industrial variances ${ }^{162}$ were requested for properties in commercial zones, a fairly large percentage was sought in osten-

154. Of the total of 15 use variances requested in this group, 12 were granted and three refused. Two of the three requests for use and zoning variances were refused. See table 1 infra.

155. 21 use and two use and zoning variances were requested in this group. See table 1 infra. However, five of these cases were concerned with similar-type uses in an area of approximately three blocks, probably presenting a unique situation and not accurately reflecting the significance of the factors in this category. The variances were requested generally for the storage of junk in blocks that were zoned " $D$ " residential, and the uses had been existing in violation for from two to four years. Thus, since the properties did have some history of industrial usage, and since there were other uses, though existing illegally, in the area, they were included in this group. The properties were located in a section of the city where only about $20 \%$ of the area was zoned for residential purposes, and consequently, as long as there was no desire to build, it would be cheaper to use the residential land for industrial purposes, rather than purchase industrial land. However, the area is gradually being utilized for residential purposes, and neighborhood associations and property owners offered strong protests against the continued industrial usage. Since the only arguments each applicant could offer were his own illegal use and the illegal uses of the other applicants, and since the protestants presented a somewhat logical argument in wanting the land used for the purposes for which it was zoned, the variances were refused in four of the five cases. In the fifth case, since the applicant proved that his property was below the street level and not immediately available for private residences, he was given a temporary non-conforming use in order to find a new location. Consequently, for all practical purposes 16 use and two use and zoning variances were requested in this group.

156. In this group, seven commercial use and one commercial use and zoning variance were requested. See table 1 infra.

157. Five of the eight properties for which commercial variances were sought were located on corners.

158. See text following note 137 supra.

159. Commercially constructed buildings were located on seven of the properties for which variances were requested.

160. Three of the commercial uses were existing in violation. See table 2 infra. In one case, the illegal use was the only history of the property, but was not existing in violation at the time the request was made. See note 139 supra.

161. See table 1 infra. One of those granted was for a temporary non-conforming use. See note 76 supra.

162. Nine of the requests were for industrial use variances and one was for both an industrial use and zoning variance. See note 155 supra and table 1 infra. 
sibly residential districts. ${ }^{163}$ As in the other classifications, ${ }^{164}$ when a request for an industrial variance was made, the Board inquired into the type of use requested, the adequacy of the existing facilities, and the nature of surrounding uses in greater detail than when the question of a commercial variance was involved. ${ }^{165}$ However, since the proposed use was of the same type as the former one or of an even higher class, again the variance was not often refused on these grounds. ${ }^{168}$

Thus, whether a commercial or an industrial variance was sought in this classification, the applicant generally was granted a variance for his property. ${ }^{107}$

Other Cases. ${ }^{108}$ - In addition to the specific factors which have been discussed, certain general principles seemed to be followed in all cases, regardless of the classification into which the case fell. Usually the fact that the property had been existing in violation of the ordinance for a number of years did not have any pronounced effect in persuading the Board to refuse a variance, ${ }^{160}$ and in a few cases seemed to serve in the applicant's favor. ${ }^{170}$ Nor was the variance denied because the requested use was sought in behalf of a purchaser of the property and the contract of sale was conditioned on obtaining a variance. Moreover, if the property for which the variance was sought was located within an area cited for redevelopment, ${ }^{171}$ the applicant generally would receive a temporary non-conforming use, probably on the theory that if the area is being redeveloped the variance would merely permit the applicant to continue in business while attempting to find a new location and, in any event, the use, of necessity, was of a limited duration.

In addition to the particular factors and general principles which seemed to govern the grant or refusal of a variance, the Board also was confronted with a maze of varied factual situations for which general rules cannot be formulated. However, in two cases a situation arose in

163. Four of the ten industrial variances requested were for properties in residential zones. Two of the four were granted variances.

164. See text following notes 136,153 supra.

165. Four of the industrial uses for which variances were requested were existing in violation. Three were refused and one was granted. See note 155 supra and table 2 infra. In the case in which the variance was granted, the only history of the property was the illegal use. See note 139 supra.

166. Of the ten industrial variances requested, six industrial use variances and the one use and zoning variance were granted, although conditions were imposed in three cases. See table 1 infra.

167. 13 use and two use and zoning variances of the 16 use and two use and zoning variances requested were granted. See table 1 infra.

168. 21 use variances and seven use and zoning variances were requested in this group. See table 1 infra. infra.

169. See, e.g., text at note 161 and notes $160,142,149,165$ supra, and table 2

170. See, e.g., text following note 142 supra and text following note 76 supra.

171. The Redevelopment Authority sends a letter containing a list of these properties, usually three or four, to the Board each week. In most cases, the Board will explain to the applicant that the property is in an area which is to be redeveloped, thus cautioning the applicant against undertaking any long-range plans. 
which a row of houses extended for approximately three-quarters of a block and the remaining properties in the block were in the next highest zoning classification which excludes attached dwellings. If an applicant wished to complete the row, a variance was granted provided the change would not encompass too large an area, usually three or four properties. ${ }^{172}$ In requests for commercial use variances ${ }^{173}$ where only one ${ }^{174}$ other similar use existed in the block, the variance was refused or conditions curtailing the conduct of the use were imposed. ${ }^{175}$ In another type of case, a commercial variance was granted where the property was situated both in a residential and a commercial zone, and the property was to be constructed in the form of a residence and used for a doctor's office in which the doctor was not going to reside. In the case of multi-floor apartment houses, stores within the building normally are planned for the use of the occupants, and variances will be granted for standard commercial uses, such as drug stores and beauty parlors. ${ }^{178}$

Some of the requests for industrial variances ${ }^{177}$ involved a situation similar to the history-type cases. ${ }^{178}$ Although in the cases in this group the applicant wished to extend a use, which had existed legally for a number of years, to an adjoining property which was zoned residential or commercial, the result was similar to that reached in the history-type situation, ${ }^{179}$ since the variance was usually granted regardless of the nominal zoning of the block. ${ }^{180}$ Moreover, unlike the results reached in the requests for commercial variances in this group, if the applicant could show that one other similar use existed in the block, he usually was granted a variance. ${ }^{181}$ In a few cases, other factors, such as the increased safety to the surrounding neighborhood, seemed to influence the Board in deciding whether or not to grant a variance. For example, in one case, an

172. Residential use and zoning variances were granted in both instances.

173. In this group commercial use variances were sought in nine cases and both a use and zoning variance were requested in one case. Two residential use and zoning variances, note 172 supra, were also requested. See table 1 infra.

174. See text following note 131 supra.

175. Of the four cases presented where another similar use existed in the block, two variances were refused, and one was granted subject to certain conditions which the applicant and protestants had agreed upon. The remaining variance was granted for the limited type business use. See text at note 126 supra.

176. Of the total of nine commercial uses requested in this group, five were granted, three were refused, and a temporary non-conforming use was granted in one case. See note 76 supra. Conditions were imposed in two of the cases. The request for both a commercial use and zoning variance was refused. The two requests for residential use and zoning variances, note 172 supra, were also granted. See table 1 infra.

177. 12 industrial use variances and four industrial use and zoning variances were requested in this group. See table 1 infra.

178. See text following note 147 supra.

179. See note 152 supra.

180. All three use variances were granted, even though in two of them the new use was located on a residentially zoned property. The one request for both a use and a zoning variance was also granted.

181. Use variances were granted in two of the three cases in which one similar use was located in the block. 
applicant wished to replace outmoded and dangerous equipment in a new building ${ }^{182}$ because the size of the machinery prohibited its installation in the existing building. The proposed building was to be situated next to the old one on a dead-end street where it would not interfere with other uses. The variance was granted probably because of its location and the increased safety to neighboring uses which would result. ${ }^{183}$

Although in all cases in which a variance is sought the applicant is required to prove that some type of hardship will be imposed on him if the request is refused, the Board seemed to take an ad hoc approach in disposing of this group of cases as contrasted with the manner in which it appeared consistently to give decisive weight to certain recurring factors when it considered the other groups of cases. Generally in this group, whether a commercial or an industrial variance was requested, the requirement for obtaining a variance seemed to be primarily that the proposed use was not too objectionable in relation to surrounding uses, and this determination was governed for the most part by specific objections of protestants. ${ }^{184}$ Consequently, the Board's approach was more negative than positive. ${ }^{185}$

Protestants. ${ }^{188}$-One of the most controversial issues in the granting of variances seemed to be the effect on the Board's decision of persons protesting the establishment of a particular use. The same question, although to a minor degree, was raised by petitions, or persons appearing at a hearing, in support of the granting of a variance. ${ }^{187}$ Despite the Board's repeated statements that the question of granting variances "was not a popularity contest," the presence of protestants seems significant when the percentage of cases in which protestants appeared and the variance was granted is

182. Both a use and a zoning variance were required, since the property was located in an "A Commercial Zone" where the type of manufacturing sought was prohibited and the new building was to cover $100 \%$ of the property.

183. Of the 12 industrial use variances sought in this group, eight were granted, although conditions were imposed in three of these cases. In three of the cases the variances were refused, and a temporary non-conforming use was granted in the remaining case. See note 76 supra. Three use and zoning variances were granted out of the four requested, but a condition was attached in one case. See table 1 infra.

184. Six of the eight use and use and zoning cases refused were protested by persons appearing at the hearing. See tables 1,3 infra.

185. Of the 21 use variances requested in this group, 15 were granted and six refused. Five of the seven use and zoning variances were also granted. See table 1 infra.

186. The effect of protestants on the Board's decisions in the cases in all of the classifications will be included in this section. Since there were relatively few cases where the only protest was by petition, only those cases in which protestants appeared at the hearing will be discussed. No distinction will be made between use and use and zoning cases, since the use of the property was always the primary reason for the protest. See note 113 supra. Of the 121 cases treated in this section of the Note, note 113 supra and table 1 infra, the issuance of the variance was contested in 46 cases. See table 3 infra.

187. Persons favoring the granting of a variance appeared at the hearings in only three or four of the cases. In about 17 cases, petitions signed by neighboring property owners, stating that they had no objection to the proposed use, were submitted. The petitions seemed to have no effect on the Board's decisions. 
compared with the percentage of non-contested variances granted. Protestants appeared in about thirty-eight per cent of the cases, ${ }^{188}$ and in those cases variances were granted about twenty-four per cent of the time, ${ }^{189}$ while variances were granted in about seventy-seven per cent of the cases in which protestants did not appear. ${ }^{190}$ Thus, in cases in which protestants did not appear, the ratio for granting variances was over three times as high as for those in which they did appear. However, these statistics do not necessarily mean that the Board was influenced only by the presence of protestants, because the types of cases in which they appeared and the specific objections that they offered must also be considered.

In over half of the cases in which no similar uses existed in the block, protestants appeared to contest the granting of the variance, ${ }^{191}$ and in all but one ${ }^{192}$ of these cases the variance was refused. This may in part account for the high percentage of refusals in cases where the variance was protested. ${ }^{193}$ When no similar uses existed in the block, the usual argument of the persons protesting the issuance of a commercial variance ${ }^{194}$ was that they had purchased properties in a residential neighborhood and that they wanted it to remain that way. The same argument was offered in opposition to the granting of industrial variances, ${ }^{195}$ and, in those cases in which the use was already existing in violation, ${ }^{196}$ the protestants also objected to the traffic and disturbance which had resulted from the conduct of the use in the past. Since the Board's policy was not to grant a variance where there were no other uses in the block, ${ }^{197}$ and since they were rather consistent in the application of that principle, except for the limited-type variances, ${ }^{198}$ the effect of the protestants on the Board in this type of case would not seem to be too significant.

There was a noticeable decline in the number of complaints against the proposed variance in those cases in which there were similar uses in the block, ${ }^{199}$ or where the property had a previous history of com-

188. Protestants appeared in 46 of the 121 cases.

189. Variances were granted in 11 of the 46 cases in which protestants appeared, or $23.9 \%$. See table 3 infra.

190. In 59 of the 75 cases in which protestants did not appear, or $78.7 \%$, the variance was granted. See table 3 infra.

191. Of the 38 cases in which no similar uses existed in the block, 20 were protested. See table 3 infra.

192. In this case a limited-type variance was granted.

193. 19 of the total of 35 refusals in protested cases involved requests for variances in blocks where no similar uses existed. See table 3 infra. There were refusals in $95 \%$ of the protested cases in which no similar uses existed in the block, whereas only $61.5 \%$ of the protested variances in the other classifications were refused.

194. 15 of the 33 requests for commercial variances in blocks where no similar uses existed were protested. Only one of the 15 protested variances was granted, see table 3 infra, and this was a limited-type variance.

195. There were five requests for industrial variances where no similar uses existed in the block, and all five were protested. See table 3 infra. infra.

196. Three of the five industrial cases were existing in violation. See table 2

197. See text following note 114 supra.

198. See note 130 supra.

199. Of the 14 variances requested in this group, see note 131 supra and table 1 infra, two were protested. See table 3 infra. 
mercial or industrial use, ${ }^{200}$ or where there was a combination of both factors. ${ }^{201}$ In the few cases in these three groups in which the granting of a commercial variance was contested, ${ }^{202}$ the objection usually was not against the commercialization of the property, but against the particular use sought. Although there was not a sufficient number of cases in these classifications to draw any definite conclusions as to the effect of protestants in objecting to a commercial use, it did not seem that their presence alone precluded the granting of the variance, although it did seem that the Board recognized their specific objections by virtue of the conditions attached to the variances. ${ }^{203}$ The majority of complaints registered in these three classifications were restricted to protests against industrial uses 204 in residential ${ }^{205}$ or commercial ${ }^{208}$ zones. The arguments usually presented were either that the protestants did not want an industrial use on residentially zoned land, ${ }^{207}$ or that they objected to the particular use sought, or, in those cases in which the use was existing illegally at the time of the request, to the way in which the use had been conducted in the past.203 Generally, unless the protestants were able to prove that the land could be utilized for residential purposes or to point out a specific evil connected with the use, their attempts to oppose the variance were ineffectual. ${ }^{209}$ Although it was evident that the effect of the protestants' objections in both the commercial and industrial cases in which they appeared was an

200. Six of the 18 variances requested in this group, see note 140 supra and table 1 infra, were protested. See table 3 infra.

201. In this group, of the 23 variances requested, see note 155 supra and table 1 infra, nine were protested. See table 3 infra.

202. Of the nine commercial variances requested where there were other similar uses in the block, see note 132 supra and table 1 infra, only one was protested. None of the seven commercial variances requested where the property had a previous history, note 141 supra and table 1 infra, were protested. Where there were other similar uses in the block and the property had a previous history, two of the eight requested, see note 157 supra and table 1 infra, were protested. See table 3 infra.

203. Of the three protested, one was refused and conditions were imposed in the other two. See table 3 infra.

204. One of the five industrial variances sought where similar uses existed in the block, see note 137 supra and table 1 infra, was protested. Of the 11 industrial variances requested where the property had a previous history, see note 147 supra and table 1 infra, six were protested. Where the property had a previous history and other similar uses existed in the block, seven of the 15 variances requested, see notes 155, 162 supra and table 1 infra, were protested. See table 3 infra.

205. Of the 14 industrial variances protested, eight were located in residentially zoned blocks.

206. Six of the 14 properties were commercially zoned.

207. This was the primary argument presented in the one case in which there were other similar uses in the block, in one case in which the property had a previous history, and in five where there were both a previous history and other similar uses. The variances were refused in four of the cases where there were both previous history and similar uses.

208. This was the major argument in seven cases, five of which had previous histories, with four existing in violation, and two of which, both existing in violation, had previous histories and were located where other similar uses existed in the block. Three of the five in the history classification were refused, and both variances were refused where the property had a previous history and there were other similar uses in the block.

209. Of the 14 industrial variances protested in these classifications, five were granted and nine were refused. See table 3 infra. Two of those granted were for temporary non-conforming uses. See note 76 supra. 
important factor, it did not seem that the mere fact that a large number of protestants appeared at the hearing would automatically guarantee the refusal of the variance or override the other factors which the Board apparently considered.

Although the percentage of cases in which protestants appeared and the variance was refused in the "other cases" classification ${ }^{210}$ did not differ materially from the classifications previously discussed, with the exception of the group in which no similar uses existed in the block, ${ }^{211}$ the effect of the protestants on the Board's decision seemed to be more pronounced. This may have been because it was more difficult to ascertain the other factors which governed the grant or refusal of the variance, and consequently the efficacy of the protestants' objections may be unduly accentuated. However, in most of the commercial and industrial use cases in this group in which protestants appeared, the use was refused, ${ }^{212}$ and even in a case where an applicant for a commercial variance had made a fairly convincing showing of unnecessary hardship, conditions were attached covering the objections to the use. ${ }^{213}$

However, in all classifications persons appearing at the hearing did appear to perform two important functions. First, they served the purpose of acquainting the Board with certain conditions in the block and area in which the variance was requested which the members of the Board otherwise might not have considered because of their inability to inspect the premises, ${ }^{214}$ and secondly, they were able to point out specific evils connected with the conduct of the use, especially in those cases where the use had been existing illegally. Although specific instances may be found where a case seemed to turn on the presence or absence of protestants and their objections, as evidenced by the conditions attached to the variance, ${ }^{21 \widetilde{5}}$ the fact that only about forty per cent of the cases were protested,

210. Of the 28 requests for variances in this group, see note 168 supra and table 1 infra, protestants were present in nine of the cases. Variances were refused in six of the nine cases. See table 3 infra.

211. See note 191 supra.

212. Three of the four commercial uses and three of the five industrial uses requested were refused. See table 3 infra.

213. In this case, a single strip of land with a warehouse on one side and the rears of private homes on the other was zoned residential. The applicant wished to construct a building for office purposes and argued that no one would build a residence next to a warehouse. However, the people in the homes adjacent to the proposed use objected to the proximity of an office building to their residences and to the possible use of a driveway running along the strip of land for which the variance was requested and to the rear of their properties. The variance was granted on the condition that the driveway would not be used, that a fence would be built on the side adjacent to the homes, and that only a certain percentage of the lot would be used for commercial purposes.

214. See text preceding note 92 supra.

215. However, in a few cases these conditions are somewhat questionable at least from the zoning viewpoint. For example in one case a variance was granted on the condition that no malt beverages would be sold on the premises. The Supreme Court of Pennsylvania has held that the control of the sale of alcoholic beverages is neither a proper subject of a zoning ordinance, Sawdey Liquor License Case, $369 \mathrm{~Pa}$. 19, 85 A.2d 28 (1951), nor a factor to be considered by a zoning board in determining whether or not to grant a variance. Dooling's Windy Hill, Inc. v. Springfield Township Board of Adjustment, $371 \mathrm{~Pa} .290,89$ A.2d 505 (1952). 
and that a large number of these were in blocks where no similar uses existed, would seem to indicate that the effect of protestants on the over: all policy of the Board in granting variances is not quite so strong as often thought.

\section{TABLE 1-USE AND USE AND ZONING CASES a}

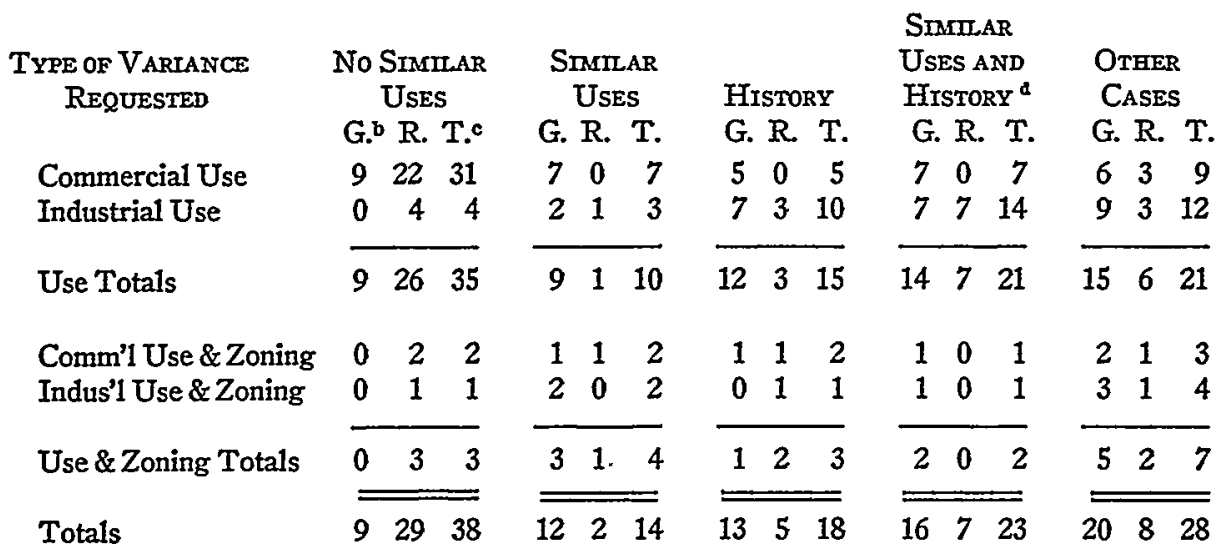

TABLE 2-USES EXISTING IN VIOLATION a

\section{TYPE OF VARTANCE REQUESTED}

Commercial Use Industrial Use

Use Totals

No SIMTLAR
USES
\begin{tabular}{ccc} 
G.b & R. T. \\
3 & 2 & 5 \\
0 & 3 & 3 \\
\hline 3 & 5 & 8
\end{tabular}

\begin{tabular}{|c|}
\hline $\begin{array}{l}\text { STMmaR } \\
\text { USES } \\
\text { G. R. T }\end{array}$ \\
\hline $\begin{array}{lll}0 & 0 & 0\end{array}$ \\
\hline $\begin{array}{lll}0 & 1\end{array}$ \\
\hline $\begin{array}{ll}0 & 1\end{array}$ \\
\hline
\end{tabular}

\begin{tabular}{ccc}
\multicolumn{3}{l}{ HistoRY } \\
G. & R. & T. \\
3 & 0 & 3 \\
3 & 3 & 6 \\
\hline 6 & 3 & 9
\end{tabular}

STMTtaR

USES AND OTHER HISTORY ${ }^{\text {a }}$

CASES

G. R. T.

G. R. T.

$\begin{array}{llllll}3 & 0 & 3 & 3 & 0 & 3\end{array}$

$\begin{array}{llllll}2 & 7 & 9 & 3 & 1 & 4\end{array}$

Comm'l Use \& Zoning Indus'l Use \& Zoning

Use \& Zoning Totals

Totals

\begin{tabular}{lllllll}
0 & 0 & 0 & & 0 & 0 & 0 \\
0 & 0 & 0 & & 0 & 0 & 0 \\
\hline 0 & 0 & 0 & & 0 & 0 & 0 \\
\hline \hline 3 & 5 & 8 & & 0 & 1 & 1
\end{tabular}

\section{$\begin{array}{lll}5 & 7 & 12\end{array}$}
a. Tables 1,2, and 3 include the use and zoning cases in which the use of the property seemed to be the primary problem considered by the Board. See note 113 supra.
b. The "Granted" columns include the cases in which temporary non-conforming uses were issued.
c. The letters "G.," "R.," and "T." denote "Granted," "Refused," and "Total."
d. This group includes the five cases discussed in note 155 supra. 


\section{TABLE 3-PROTESTED AND NON-PROTESTED USE AND USE AND ZONING CASES a}

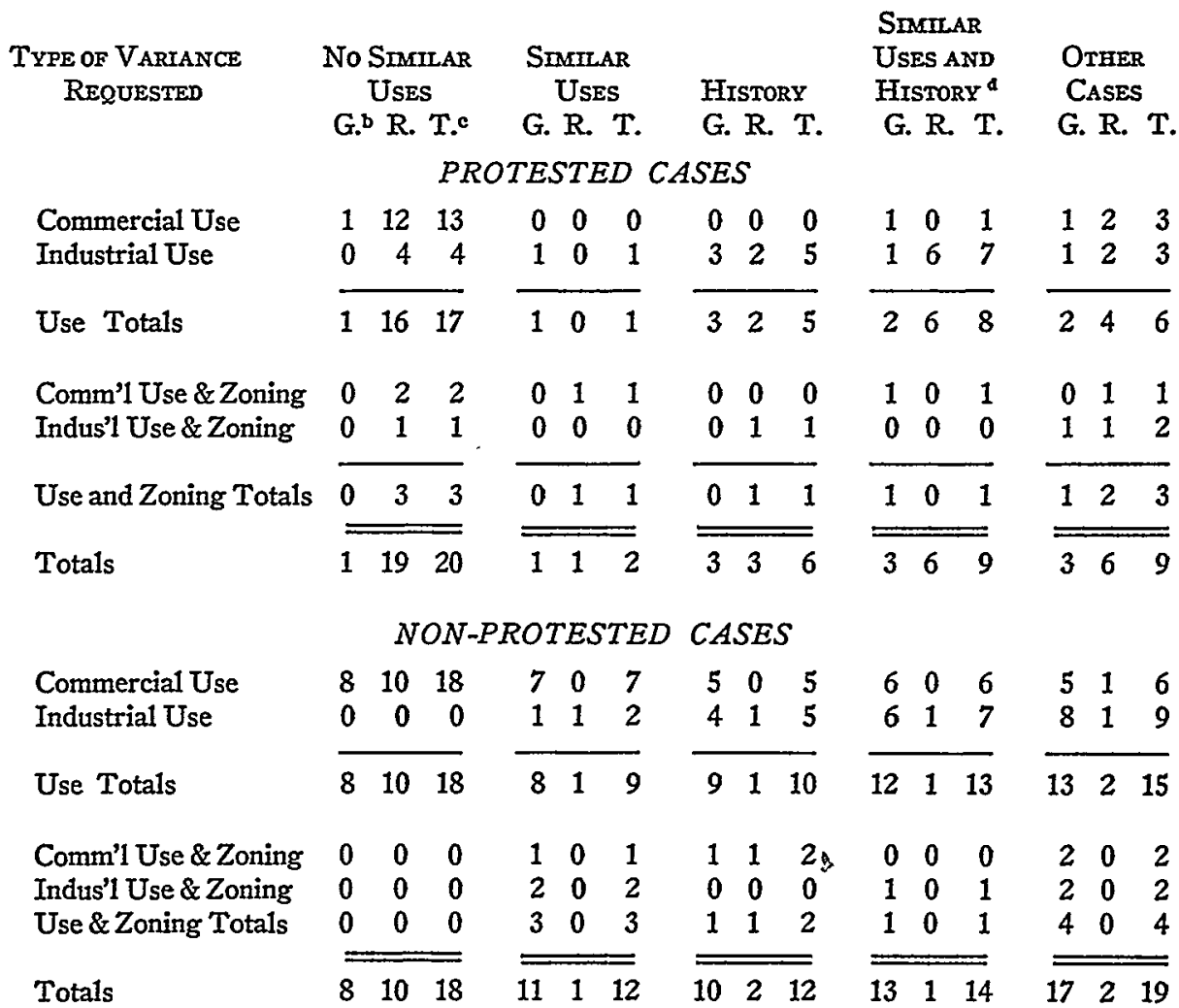

a. Tables 1,2, and 3 include the use and zoning cases in which the use of the property seemed to be the primary problem considered by the Board. See note 113 supra.

b. The "Granted" columns include the cases in which temporary non-conforming uses were issued.

c. The letters "G.," "R.," and "T." denote "Granted," "Refused," and "Total."

d. This group includes the five cases discussed in note 155 supra.

\section{Multiple Drellings ${ }^{216}$}

The major problem with which the Board was faced, at least from the number of cases in which a variance was sought, involved requests for variances for multiple dwellings. Over one-third of the cases which were heard each week involved this type of situation. ${ }^{217}$ The

216. 198 cases were included in this group. Six cases were presented in which multiple dwellings were not permitted in the district. Of the six, three were either withdrawn or refused because the applicant did not appear at the hearing. The remaining three were granted, one of them being protested. See notes 98 and 112 supra. 192 cases were concerned with requests for use variances where the property was deficient in locational requirements. Of the 192 cases, 16 were either withdrawn or decisions were not available; this section of the Note will deal with the remaining 176 cases.

217. See text at note 97 supra. 
variances usually were sought in districts in which multiple dwellings were permitted, but a use variance was required because the property did not meet the locational requirements of the ordinance. ${ }^{218}$ Over onehalf of the variances were sought for dwellings for three families, and most of the remaining ones were for from four to six families. ${ }^{219}$ In a large number of the cases, the uses already were existing on the premises in violation of the ordinance, ${ }^{220}$ and rarely were there any protestants to oppose the variance. A large percentage of the variances were requested in already congested row-house districts where other multiple dwellings, ${ }^{221}$ existing both legally and illegally, were prevalent. The Board usually granted the variance if the applicant could show that a number. of other multiple dwellings existed in the block and that each of the proposed apartments would have its own kitchen and bathroom facilities and a minimum floor area of four hundred square feet. ${ }^{222}$ In most cases, these conditions were required in order to obtain a variance, regardless of the extent to which the property was deficient with respect to the locational requirements. Approximately seventy-five per cent of the variances for three families ${ }^{223}$ and about forty per cent of the variances for over three families ${ }^{224}$ were granted. The same problem exists here as in the cases discussed previously, ${ }^{225}$ with regard to the granting of variances in the past, and whether to continue the practice and thereby permit each new variance to become a further arguing point for the future. However, in the multiple-dwelling cases the evil is not so much that the zoning of the block will be changed, but that the population of the block will increase without any relation to the locational requirements of the ordinance.

\section{See note 83 supra.}

219. 91 of the 176 cases, or $51.7 \%$, were for three families, 33 were for four, 22 for five, 21 for six, and nine for over six families.

220 . Of the 72 refusals, 48 of the uses, or $66.7 \%$, were existing in violation. Since the fact that the use was existing in violation did not seem to have any adverse effect on the Board's decision in other cases, see text at note 169 supra and table 2 supra, it would seem that the number of violations in cases where the variance is granted would be about the same as where the variance is refused.

221. 110 variances were sought in two areas of the city.

222. However, two recent developments may have an effect on the Board's policy. A decision rendered in the latter part of the summer, although affirming the Board's refusal of a variance for a multiple dwelling, advised the Board not to apply general policy formulations but to consider each case on its own particular facts. Hinton v. Philadelphia Zoning Bd. of Adjustment, $88 \mathrm{~Pa}$. D. \& C. 265 (Philadelphia C.P. 1954). In addition, the new housing code which became effective January 1, 1955, requires only semi-private bathrooms, while the Board required separate facilities. The argument could be made that the Board's standard should not be any higher than the one prescribed by the new code.

223. 69 of the 91 were granted, or $75.8 \%$.

224. Of the 85 requested, 35 were granted, or $41.2 \%$. 104 of the total of 176 requests for multiple dwellings were granted, or $59.1 \%$.

225. See text following note 137 supra. 


\section{Zoning Variances ${ }^{228}$}

The ordinance, in general, requires that all buildings be situated a certain distance from the street and also specifies rear and side yard dimensions and the percentage of the lot that may be utilized for building purposes, the requirements differing in each district. ${ }^{227}$ When a building is to be constructed on the lot, or when an addition is to be made to a building already in existence, a zoning variance must be obtained if the construction or addition does not conform to the locational requirements outlined in the ordinance. If the use which is to be made of the proposed building, or of an addition to an existing building, is not permitted in the district where the property is located, then, in addition to the zoning variance, a use variance is also required. ${ }^{228}$

The cases in which both a use and a zoning variance had to be obtained are divided into two groups. The first group, which was discussed previously, ${ }_{2}^{229}$ consisted of cases in which the proposed construction or addition involved a request for the introduction of a use on the property for the first time or the legalization of a use which had existed illegally for a period of time. Although in these cases the primary concern of the Board seemed to be with the use of the property, ${ }^{230}$ its test for zoning also had to be met, and the situation did arise where the property met the test of unnecessary hardship so far as the use of the property was concerned, but a zoning variance was refused because it did not meet the requirements for an addition. 231 The group which will be discussed in this section involved cases in which either a non-conforming building was to be destroyed and replaced, ${ }^{232}$ or a use variance previously had been granted for the property and the applicant wished to extend it by means of the proposed addition. ${ }^{233}$ Since the use had existed legally for a number of years, and since in most cases the Board previously had authorized the particular use of the property, the question of zoning was the major prob-

226. This section of the Note includes all of the 94 requests for zoning variances and 15 of the requests for both use and zoning variances. See note 113 supra and text following note 228 infra.

227. For the locational requirements of the various districts see the sections of the ordinance cited in notes 55-61 supra.

228. For example, if an applicant wished to convert a single family dwelling in a "D" residential zone into a grocery store and to extend the building to cover the entire rear yard for use in connection with the business, a use variance would be required because a grocery store is not permitted in a " $D$ " residential zone, and a zoning variance would be required because the proposed construction on the property would result in non-conformance with the locational standards of the ordinance.

229. See text following note 113 supra.

230. See note 113 supra.

231. See, e.g., the case discussed in note 76 supra.

232. Although the ordinance permits a non-conforming building to be expanded $25 \%$, Prilla. Zoning Ordinance $\$ 4(6)$, if the non-conforming building is totally destroyed, except in the case of fire or legal condemnation, it is the policy of the Zoning Division to require a variance to be obtained in order to rebuild.

233. There were 15 cases in this group. 
lem.234 The remaining cases which will be discussed in this section involved requests for constructions or additions in commercially ${ }^{235}$ or residentially ${ }^{236}$ zoned districts where, although the use was permitted, the alterations would violate the locational provisions of the ordinance and consequently only a zoning variance was required.

The Board, in the cases where only a zoning variance was requested or where the zoning question was the major problem, usually granted the variance if the construction or extension would not interfere with the neighboring uses. However, in practically all of the cases, the Board considered only the blocking of light and air when determining what amounted to an interference with neighboring uses. Since the applicant usually was seeking the variance for a rear addition to a building located in a row of buildings, the primary concern of the Board was whether the construction or addition would result in a blocking of light and air from the rears of the buildings and properties situated on either side of the applicant's property and from the remaining buildings and properties in the row. Consequently, the Board usually permitted an addition of three feet, especially in the residential cases where the replacement of a wooden structure was proposed, and permitted any further construction to the extent that the buildings on either side of the property, or in some cases the other buildings in the row, had been increased.

\section{Exceptions ${ }^{237}$}

Unlike the requirement of proving unnecessary hardship when requesting a variance, an applicant may obtain an exception, where its issuance is permitted by the ordinance, by proving that the proposed use of the property will not be detrimental to the health, safety and welfare of the neighborhood. Although the ordinance authorizes the Board to grant certificates of exception in eight different instances, ${ }^{238}$ a majority of the cases decided during this study fell into two categories. The first involved the open air parking of automobiles in residential or commercial districts, ${ }^{239}$

234. 11 of the 15 cases involved requests for extensions of uses which previously had been authorized by the Board.

235. 16 of this type case were heard.

236. 59 cases involving residential zoning questions were presented, while 19 cases were concerned with the extension of properties including both a business and a residence.

237. 80 requests for certificates of exception, which are termed reference cases by the Board, were presented, with ten requiring zoning variances in addition to the certificate, and two being concerned with non-conforming uses. In addition to the two non-conforming use cases, 13 other cases will not be included in the discussion because of the unavailability of decisions or because refusal was due to the failure of the applicant to appear at the hearing or to improper posting of the property. This section will be concerned with the remaining 55 exception and ten exception and variance cases.

238. Phila. Zoning Ordinance $\$ \$ 16(28)-(37)$, as amended, July 24, 1953; 20.4(6), added by 1951 ORDINANCES OF THE CITY OF PHILADELPHIA 527; $20.45(6)$, added by 1952 id. $379 ; 21(46) ; 21(46 \mathrm{t} / 2)$, added by 1936 id. $166 ; 26(1) ; 26(6)$, as amended, 1942 id. $99 ; 26(9)$.

239. Phila. Zoning Ordinance $\S 26(6)$, as amended, 1942 Ordrnances of the City of Philadelphia 99. 
and the second was concerned with the establishment of specific uses in commercial zones. 240

The parking lots were for the use of the public, ${ }^{241}$ accessory to a business for the convenience of customers, 242 or for the private use of the applicant in his business. ${ }^{243}$ In most of these cases, the uses were sought in commercial districts, ${ }^{244}$ where other parking lots existed, or where no residences were in proximity to the proposed use, and in about eighty per cent of these cases the certificates were granted. ${ }^{245}$ The refusals generally were for properties in residential districts ${ }^{246}$ where no other lots existed. In general, the parking lots were not contested, but the effect of the protestants in those cases in which they were, seemed significant. In those cases in which there were protestants, the objection was either to the increased traffic and commercialization that would result, or, if the objector owned the property adjacent to the proposed lot, to the effects on his residence. In all cases in which protestants appeared, the certificate was either refused, or a condition was attached to the certificate covering the protestants' objections. ${ }^{247}$ About the same results as in the parking-lot cases were evidenced in requests for used car lots, and they both seemed to present a similar problem so far as increased traffic and commercialization were concerned. All the requests were made in commercial zones where similar uses were in existence, the only refusals being where the proposed use was of land situated between private residences. ${ }^{248}$ The Board in all cases in which certificates were granted for parking and used car lots required that the lot be hard-surfaced, that lights not shine on the neighboring properties, and that no banners be strung across the lot. In other cases, where the Board thought that a specific evil might arise, a condition prohibiting the anticipated objection also was attached. ${ }^{249}$

240. Phila. Zoning Ordinance §16(28)-(37), as amended, July 24, 1953.

241. Certificates were requested in five such instances. See table 4 infra.

242. Of the seven certificates requested for accessory parking, four of them were for banks. See table 4 infra.

243. Certificates were requested in 12 of these cases. See table 4 infra.

244. In 15 of the cases in which certificates for parking lots were requested, the properties were located in commercial zones; in five, in commercial and residential zones; and in four, in residential zones.

245.19 of the 24 , or $79.2 \%$, were granted. See table 4 infra.

246. Of the four properties located in residential zones, see note 244 supra, three were protested and refused, and one was granted after the applicant and protestants had reached an agreement.

247. The certificates were protested in eight cases. In five, the certificates were refused; in two, the certificate was granted after the applicant and protestants had reached an agreement which was incorporated into the grant of the certificate; and in one, a condition was attached to the certificate satisfying the objections of the protestants. See table 4 infra. infra.

248. Of the six requests for certificates, four were granted. See table 4

249. For example, in one case in which a certificate was requested for a used car lot,. one of the Board members noticed from the photograph that some of the cars were parked on the sidewalk. The certificate was granted on the condition that there would be no encroachment by cars on the sidewalk. 
The same pattern seemed to be followed in requests for certificates with regard to those uses sanctioned in commercial zones. ${ }^{250}$ The predominant uses for which certificates were sought were auto repair shops, ${ }^{251}$ gasoline stations ${ }^{252}$ and dry cleaning plants. ${ }^{253}$ In a number of the cases in which requests were made for auto repair shops, the building was an existing public garage and apparently the use was sought in conjunction with the garage, ${ }^{254}$ or else a number of other similar uses existed in the block. As in the parking-lot cases, a high percentage of certificates were granted, a low percentage of protestants appeared, and in those cases in which they did appear they seemed to have an important effect on the decisions. ${ }^{255}$ In the case of gasoline stations, in addition to the certificate, the applicant was usually required to obtain a zoning variance because the gasoline pumps violated the setback requirements. ${ }^{258}$ Most of the certificates were sought for corner properties, ${ }^{257}$ in some cases replacing existing stations, ${ }^{258}$ and again the certificates and variances were normally granted, after the complaints of those objecting had been satisfied. ${ }^{259}$ The usual requirement for obtaining a certificate for a retail dry cleaning plant seemed to be that a certain type cleaning solution be used, and that the applicant submit a photostat of the state-approved plans. Most of those requested were granted, ${ }^{260}$ and, in the few instances in which protestants appeared, their objections did not seem as readily acceptable by the Board as in the other types of cases. ${ }^{261}$

It did not seem surprising that a large percentage of certificates of exception was granted, since the applicant did not have to prove unnecessary hardship, but merely that the proposed use was not detrimental to the health, safety and welfare of neighboring property owners, and since most of the certificates were requested in commercial zones where there were other uses similar to, or of an only slightly higher type than, the one

250. 33 certificates were requested in this group, with nine requiring variances. infra.

251. Ten of the certificates were requested for auto repair shops. See table 4

252. Seven of the cases were concerned with certificates for gasoline stations, where variances were also required. See table 4 infra.

253. Retail dry cleaning certificates were requested in seven cases, and a certificate and a variance were sought in one case. See table 4 infra.

254. The condition existed in five of the ten cases.

255. Eight of the ten certificates were granted, with two being protested and refused. See table 4 infra.

256. See note 252 supra.

257. Six of the seven were corner properties.

258. In four of the cases, existing stations were being replaced or altered.

259. All seven certificates and variances were granted. Three of the cases were protested, with conditions being attached in two of the three. See table 4 infra.

260. Six of the seven certificates requested for dry cleaning plants were granted. The request for the certificate and variance was refused. See table 4 infra.

261. Three of the cases were protested, but in only one was the certificate refused. See table 4 infra. 
requested. ${ }^{262}$ However, protestants and the objections that they offered seemed to have a greater effect on the Board than in the variance cases, since in practically all cases in which they appeared, the certificate was refused or a condition satisfying their objection was attached.

\section{TABLE 4-EXCEPTIONS}

TyPe of Exception ReQuested

Parking Lots
Public
Accessory
Private
Used Car Lots
Auto Repair Shops
Gasoline Stations
Dry Cleaning Plants
Gen'I Indus'l
Miscellaneous

Totals

\section{DeCrstons}

G. R. T. ${ }^{a}$

$\begin{array}{lll}4 & 1 & 5\end{array}$

$\begin{array}{lll}5 & 2 & 7\end{array}$

$\begin{array}{lll}10 & 2 & 12\end{array}$

$\begin{array}{lll}4 & 2 & 6\end{array}$

$\begin{array}{lll}8 & 2 & 10\end{array}$

$\begin{array}{lll}7 & 0 & 7\end{array}$

$\begin{array}{lll}6 & 2 & 8\end{array}$

$\begin{array}{lll}2 & 0 & 2\end{array}$

\begin{tabular}{lll}
6 & 2 & 8 \\
\hline
\end{tabular}

$\begin{array}{lll}52 & 13 & 65\end{array}$

\section{Protestants}

G. R. T.

112

$\begin{array}{lll}0 & 2 & 2\end{array}$

$\begin{array}{lll}2 & 2 & 4\end{array}$

$\begin{array}{lll}0 & 0 & 0\end{array}$

$\begin{array}{lll}0 & 2 & 2\end{array}$

$\begin{array}{lll}3 & 0 & 3\end{array}$

$\begin{array}{lll}2 & 1 & 3\end{array}$

$\begin{array}{lll}0 & 0 & 0\end{array}$

$\begin{array}{lll}0 & 1 & 1\end{array}$

$\begin{array}{lll}8 & 9 & 17\end{array}$
Existing IN VIOLATION G. R. T.

a. The letters "G.," "R.," and "T." denote "Granted," "Refused," and "Total."

\section{Evaluation}

Since it is at the apex of the administrative system, a Board of Adjustment is important and necessary for the proper functioning of a zoning ordinance; but its efficacy can be impaired by insufficient enforcement of the ordinance at the lower administrative level. Regardless of how exacting a Board may be in its requirements for granting a variance or exception, the effect of the Board's action becomes insignificant if property owners may violate the ordinance without fear of detection. Although this extreme situation does not exist in Philadelphia, it is apparent from the number of uses existing in violation, from the length of time this situation has existed in some cases, and from the inadequate method of detecting violators, that a larger staff is needed to enforce the ordinance. Moreover, the present policy of permitting violators to escape the imposition of a sanction by ceasing the illegal use or by obtaining a variance on appeal to the Board militates against the desired effects of the ordinance to deter wilful violators and to arouse an awareness of the ordinance in those who are not cognizant of its provisions.

The primary administrative difficulties stem from the lack of time which the members of the Board have to handle variance and exception

262. Eight other certificates were requested in the commercial classification, with six being granted, and two, one of which was protested, being refused. See table 4 infra. The remaining two cases were concerned with the establishment of uses in a general industrial zone, which were not listed in the ordinance, and consequently required certificates. Phila. Zoning Ordinance $\$ 21(46)$. Both certificates were not protested and were granted. See table 4 infra. 
cases. The inability of the Board members to consider each case thoroughly and to inspect the property of each applicant is due both to the large number of cases which must be decided each week, and to the fact that a man with the necessary capability and experience in the field cannot be expected to devote all his time to his position on the Board when the compensation is only fifty dollars per session. The impossibility of considering each case fully may result in the unjust treatment of many applicants. Since the Board does not give any reason why a variance has been granted or refused, only an attorney who handles cases every week and therefore has some idea of the standards required by the Board can effectively argue a case. If sufficient time were available, the Board could cure this inequity by providing reasons for its decisions and by examining more carefully the facts of each case. Furthermore, in order to hear each case in the minimum amount of time, the Board has formulated general rules and does not permit the applicant to cite its previous decisions as authority for the disposition of his case. However, the courts continue to emphasize that each case must be decided on its particular facts and to admonish the Board not to formulate general rules. A compromise might be reached by allowing the applicant to cite previous decisions of the Board in which a situation similar to his existed, and by permitting the Board to explain why a deviation from the general rule is necessary.

An examination of the use-variance cases indicates that, although the courts have not clearly enunciated the area which should be considered with regard to the conditions surrounding the applicant's use, the Board in most cases has limited its scope of inquiry to the block in which the applicant's property is situated. Although the consideration of a oneblock area probably is sufficient to determine the immediate effect of a particular use on surrounding uses, it would seem that a somewhat larger frame of reference should be utilized for considering the interrelation of a use with the existing and future zoning plans for the particular and neighboring zones and for the entire city.

Whatever the proper area may be, it must be determined which conditions existing within that area should be taken into account when deciding a particular case. Although the Board and the courts seem to agree as to which factors should be considered, there appears to be some disagreement as to the number of these factors which should be required in order to grant the variance. Generally, if one condition exists which the Board considers significant, it will grant a variance, while the courts require that a number of these conditions be present before they will affirm the issuance of a variance.

Since the courts have not sanctioned the arguments that a use should be granted, where no similar uses exist in the area, because of the need for the particular use or because of reasons personal to the applicant, the Board would seem to be legally sound in refusing to accept them. In addition, it would seem that the correction of the need, if it exists, should be 
accomplished by a map change, rather than on an individual and preferential economic basis. Since the home occupation and limited business variances seemed to be granted primarily on an economic basis, the Board may have placed undue emphasis on this factor in opposition to the admonitions of the courts. However, since only a few of these variances were granted and since rigid restrictions were imposed in each case, the effect of the Board's action does not seem too significant.

Although the courts have not strongly emphasized that the existence of similar uses in the zone is an improper factor, a policy of granting variances merely on the strength of other uses in the block presents certain difficulties. For all practical purposes, this policy represents the haphazard zoning of particular areas. In addition, if the Board is to be consistent in its policy, each variance will become a further arguing point for any future applicant. A better solution would be for the Board to recommend a zoning change when it thinks that there are a sufficient number of uses of a class lower than that for which the district was zoned.

A different question is presented where the history of the property and the present structure of the building is involved. Although again the courts have not completely clarified the effect that this factor should have on the Board's decision, there is little danger that a variance will lead to a gradual change in zone. In addition, in this situation, the granting of a variance to one applicant does not provide a valid argument for the granting of variances in the future for the properties in his locality. Moreover, particularly in the case of an industrial use, the Board would seem to be justified in finding that a hardship would exist if the variance were refused, since the applicant would be forced to demolish the building and sell the land. However, the mere existence of a hardship should not result in the granting of variances in every case, since this factor must be balanced against the detrimental effects that the use would have on surrounding properties.

Since practically none of the cases involving multiple dwellings have been appealed to the courts, the Board has had relatively little assistance in deciding what factors to consider in this type of case. Although the minimum standards that the ordinance imposes for multiple dwellings are concerned mainly with sufficient light and air for the occupants, the conditions that the Board requires are concerned primarily with interior living conditions. Even though the Board must formulate general rules because of the lack of time to consider each case thoroughly, it should attempt to correlate the number of apartments permitted for a particular dwelling with the extent to which the property is deficient in the locational requirements.

The primary difficulty in comparing the standards applied by the courts and by the Board in the cases involving requests for zoning variances is the complete dissimilarity between the types of cases considered by the courts and the bulk of the cases heard by the Board. Those appealed to 
the courts usually involved properties in the higher classified residential districts, while the majority of the cases before the Board were concerned with additions to row houses in the lower classified residential districts. However, the standards applied by the Board did seem to afford adequate protection to the neighboring properties by providing them with sufficient light and air. The treatment accorded the exception cases seemed to reflect the attitude of the courts in that the Board granted certificates primarily on the basis of the existence of other similar uses in the area.

Although in most cases the Board appeared to follow the courts by attaching to a variance or exception only those conditions which had a reasonable relationship to the conduct of the use and to the protection of surrounding uses, occasionally it seemed that the attachment of the condition was used merely to pacify protestants. However, the Board usually followed the courts in considering the objections themselves rather than the number of protestants who promulgated them.

In general, the Board decided variance and exception cases in a manner consistent with the courts' decisions; but, primarily because of the insufficient time which could be devoted to each case, the Board attempted to categorize the cases according to the presence or absence of one significant factor. Since the lack of time underlies most of the difficulties of the Board, an attempt should be made either to alleviate the situation or, at least, to recognize the policy which the Board must adopt if the situation continues. The problem would be partially solved by making the Board members full-time officials, but this may be impractical because of the lack of funds. Another solution would be to decrease the number of cases heard each week. The explanation for so many cases probably is the substantive inadequacy of the present ordinance, the unrealistic zoning of certain areas of the city, and the apparent indiscriminate granting of variances in previous years. However, since an adequate solution will involve a considerable amount of time and effort, the most important step that can be taken at present is for the courts to realize that, under conditions prevailing in Philadelphia, they can no longer consider the variance as a peculiar and relatively rare request for a deviation from the ordinance. 